\title{
Building a method for the study of the Mesolithic- Neolithic transition in Portugal
}

\author{
Mary J ackes 1, Christopher Meiklejohn2 \\ 1 Department of Anthropology, University of Alberta, Edmonton, Canada \\ mjackes@ualberta.ca \\ 2 Department of Anthropology, University of Winnipeg, Winnipeg, Canada \\ c.meiklejohn@uwinnipeg.ca
}

\begin{abstract}
This paper focuses on the agricultural transition in Portugal and on demography across this transition, concentrating on two key skeletal samples, the Mesolithic shell midden of Cabeço da Arruda and the Neolithic burial cave of Casa da Moura. It extends our previous work on the demography of the transition and the methodology surrounding its determination. We explain our method for determination of the number of individuals in samples where whole skeletons cannot be used. We then concentrate on the estimation of fertility, placing it within limits of biological feasibility, sample inadequacies, and vagaries of age assessment. From our analysis, which includes an examination of historical issues with the sites, we argue for regional population continuity between 8000 and 6000 calBP, and suggest that Neolithic life-ways slowly intensified, founded on important elements deriving from the late Mesolithic, with changes that included increased fertility through shortening of the birth interval.
\end{abstract}

IZVLEČEK - V članku se osredotočamo na prehod v kmetovanje na Portugalskem in na demografijo pri tem prehodu, še posebej na dva ključna vzorca skeletov - mezolitsko najdišče školjčnih lupin Cabeço da Arruda in neolitska jama s pokopi Casa da Moura. To je nadaljevanje naših dosedanjih raziskav demografije prehoda in s tem povezano metodologijo. V članku razložimo našo metodo za določevanje števila posameznikov v vzorcih, kjer ni mogoče uporabiti celih skeletov. Nato se osredotočimo na oceno rodnosti glede na biološko zmožnost, neustreznost vzorcev in glede na omejitve pri ocenah starosti. Na osnovi naših analiz, ki vključujejo tudi zgodovinske vidike raziskav najdišč, zagovarjamo regionalno kontinuiteto prebivalstva med 8000 in 6000 calBP. Menimo, da se je neolitski način življenja počasi intenziviral na temelju pomembnih elementov iz poznega mezolitika, spremembe pa so vključevale naraščanje rodnosti in skrajševanje časovnega razmika med rojstvi.

KEY WORDS - Mesolithic; palaeodemography; human skeletons; Muge

The dynamics of the agricultural transition constitutes one of the most debated areas of Holocene Old World archaeology (see e.g. Ammermann and Biagi 2003; Price 2000). In this paper we will focus on work in Europe and examine the use of human skeletal material, which is critical to any discussion on a demographic transition and population growth contemporaneous with the agricultural transition.

Bocquet-Appel (2002) argues that there was a Mesolithic/Neolithic transition in Europe entailing a major change in the nature of population growth. We will explore this concept using skeletal samples from Portugal that span the transition. In particular, we will investigate the large samples of apparently primary burials excavated at the Mesolithic midden sites of the Muge River valley, as compared with the equally large but quite differently interred Neolithic skeletal samples from sites such as the ossuary cave of Casa da Moura in the Estremadura. We will explore, in more depth than previously, the determination of numbers of individuals found within these 
sites, an issue which is crucial to their use in demographic analyses. As part of this discussion we will use published and unpublished data to examine the history of excavation of the Muge sites, focussing on Cabeço da Arruda, among the most complex of any Mesolithic site in Europe, with a history of multiple excavations going back to the 1860 s.

\section{SKELETAL SAMPLES OF THE PORTUGUESE MESOLITHIC/NEOLITHIC TRANSITION AND THEIR CONTEXT - INTRODUCTION}

The sites that will be discussed in this paper in varying degrees of detail are in central and southern Portugal (Fig. 1). The two Mesolithic sites, Cabeço da Arruda (henceforth Arruda) and Moita do Sebastião (henceforth Moita), are near the exit of the River Muge into the Tagus, about $30 \mathrm{~km}$ northeast of the current Tagus estuary. These sites have had the most complex excavation histories of any European Mesolithic burial sites. First explored between 1863 and 1865 by A. F. Pereira da Costa and C. Ribeiro, they were excavated twice again in the $19^{\text {th }}$ century, in 1880 by Ribeiro and again later in the 1880 s by $F$. de Paula e Oliveira ${ }^{1}$. In the $20^{\text {th }}$ century, excavations occurred in two phases. A. A. Mendes Corrêa excavated Arruda in 1937 with his collaborators, R. da Serpa Pinto, J. R. do Santos Junior and A. Ataíde, following several years of excavation in the early 1930 s at Cabeço da Amoreira. In 1951 the bulldozing of the Moita site led to intervention by Mendes Corrêa and excavation from 1952 to 1954 by J. Roche and 0. da Veiga Ferreira. Following upon this, excavations were undertaken at Cabeço da Amoreira between 1958 and 1967 under the direction of Roche and Veiga Ferreira, and extended to Arruda in 1964 and 1965. Finally, new excavations at Amoreira have begun under the direction of J. M. Rolão and M. Roksandić, with some section cleaning and stabilization at Arruda. Our primary discussion in this paper is of Arruda, while papers on Moita are in preparation (Alvim, Jackes in prep.; Jackes, Meiklejohn in prep.).

The major Neolithic site is Casa da Moura, a burial cave in the Estremadura, a karstic region north of Lisbon. It was first excavated in the 1860's by Delgado (1867) and re-examined by L. G. Straus in the

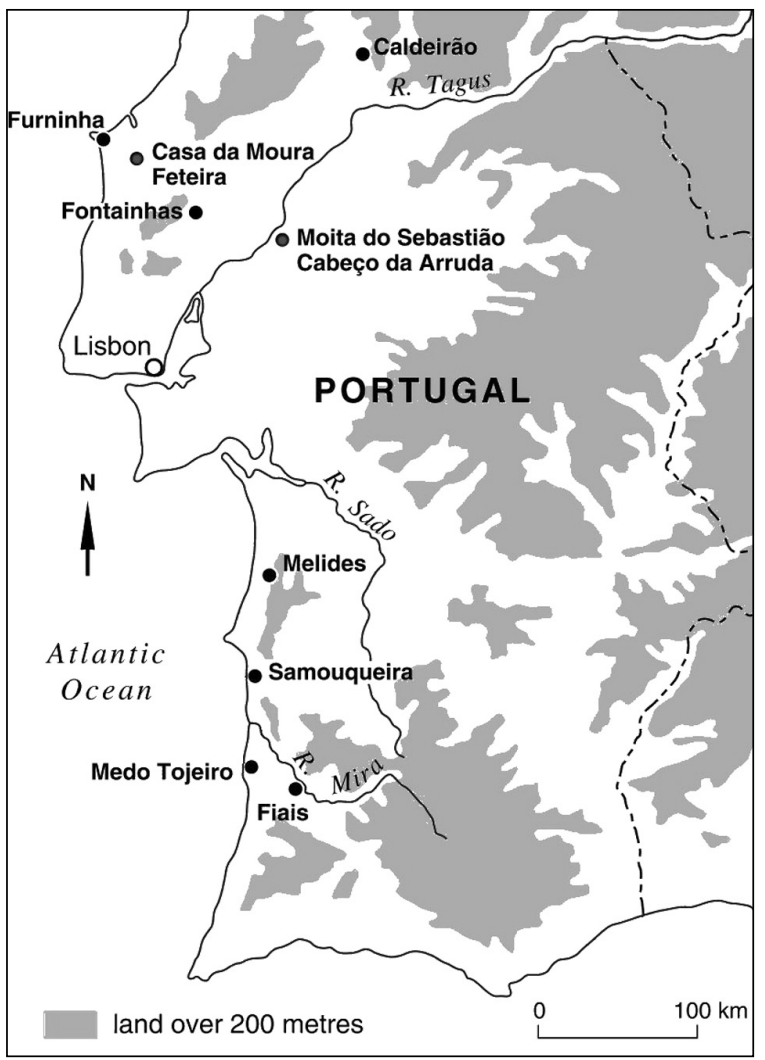

Fig. 1. Central and southern Portugal showing the location of a number of important Mesolithic and Neolithic sites.

1980's (Straus et al. 1988). Other sites noted in Figure 1 will be discussed where relevant.

The three surviving midden sites of the lower Muge valley lie on either side of a broad area of marsh through which a channel for the river has been dredged (Fig. 2). Moita and Amoreira lie just over $1 \mathrm{~km}$ apart on the south side of the valley, with Arruda just over $2 \mathrm{~km}$ to the northeast of Amoreira on the north side of the valley. Arruda lies on the edge of the valley flood plain and has been impacted by flooding, while Moita now lies under a rice processing installation ${ }^{2}$.

Work in the 1950s and 1960s produced the first absolute dates for the Muge series, based on charcoal. These were from the Saclay laboratory, very early in the history of ${ }^{14} \mathrm{C}$ dating, with standard errors of 300 to 350 years. At Moita they provided a date for the base of the sequence (layer II) of $7080 \mathrm{bp}^{3}$ (Roche 1957). At Arruda they provided bracketing dates

1 See, e.g., Cardoso and Rolão 1999/2000, Newell et al. 1979 and Roche 1972. Roche was incorrect in stating that an 1892 excavation took place (Roche 1972b.75).

2 The lower Muge Valley is now structured as paddies for the intensive cultivation of rice. Other shell middens were destroyed in the $19^{\text {th }}$ century for the planting of vines.

3 Uncalibrated dates are expressed as bp, while calibrated dates are expressed as calBP. 


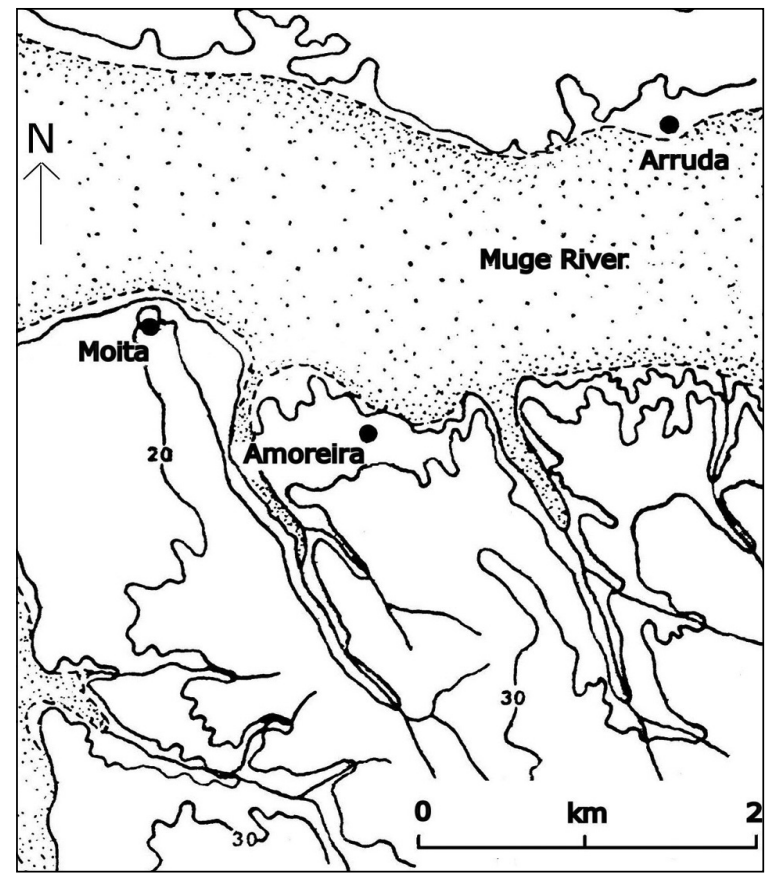

Fig. 2. The classic Muge Mesolithic sites (after Roche 1972.20.Fig. 2). The Muge is an area of marsh (stippled) through which a drainage canal has been dredged.

for the base and top of the site of 6430 to $5150 \mathrm{bp}$ (Roche 1965a; 1965b). At Amoreira there were also bracketing dates of 7030 to 6050 bp (ibid.). Any overall chronology of the sites based on these dates was enigmatic at best and none of these dates could be firmly linked to any of the human skeletal material. The best date for Moita was 7080 $\pm 130 \mathrm{bp}$ for basal breccia charcoal (H2119/1546: Roche, Veiga Ferreira 1972/73) and for Amoreira, also on charcoal, 7135 \pm 65 bp (Hv-1349: Soares, Cabral 1984; Kalb 1989). No good dates were available for Arruda.

As part of our re-examination of the Muge skeletal series in the 1980s the authors, working with David Lubell, instituted a program of new AMS ${ }^{14} \mathrm{C}$ dates directly on the human skeletal material (Lubell et al. 1994) to which new dates have been added, deriving for example from the most recent excavations at Arruda by Rolão and Roksandić (Roksandić in press). The overall results (Fig. 3) suggest a sequential chronology, though the actual occupation of the sites may overlap. Moita seems to be the earliest with dates covering the period 7240 to $6810 \mathrm{bp}$. Amoreira with dates from 6630 to 6550 bp seems younger but needs further work. Arruda seems to fit in between, with dates of 7040 to $6360 \mathrm{bp}$. The more completely dated sites suggest an approximate 400 year time span for the occupation of Moita and a slightly longer 600 years for the occupation at Arruda. The possible sequential occupation of these sites is important in terms of other data that suggest differences between the sites, both in terms of the environment and human biology (for biological variability see Jackes, Lubell 1999).

There may be evidence of a change in patterns of environmental exploitation (Fig. 4, Lentacker 1991). The graphed data are for terrestrial herbivores on the three Muge sites, derived from the representation of the relevant taxa4. The frequency of lagomorphs apparently increases between Moita and the later sites. Suids, cervids and bovids all decrease, which could involve several variables including environment and access to animals within the effective catchment zone of the sites. Some specific non-food related faunal elements may provide other clues: red squirrel (Sciurus vulgaris) bones at Arruda indicates the presence of pine forest, as opposed to the current dominance of oak (Antunes 1985). Support for increased pine in the vicinity around 7500 calBP comes from the work of van der Schriek (in prep.; van der Schriek et al. 2003), which also documents this period as the time of maximum tidewater influence in the Muge. Thus, there were environmental changes over what appears to be a quite restricted time period of the Mesolithic occupation at Muge. Resource changes would have been mediated especially by the rise and fall of the Holocene sea level resulting in a rise and fall of the important molluscan dietary sources, especially Scrobicularia plana.

While faunal data may reflect a shift in diet within the period of occupation at the Muge midden complex, we have independently studied this through use of stable isotope determinations of $13 \mathrm{C}$ and ${ }^{15} \mathrm{~N}$ (Lubell et al. 1994). Results for Moita and Arruda, together with other Mesolithic individuals, and a Neolithic series, are seen in Figure 5. The results show a trend away from marine dietary elements towards terrestrial elements. As a series, Moita appears to be more marine than Arruda and both appear to be more marine based than the majority of the Neolithic individuals. There is no major divide in the sequence comparable to the marked shift documented for Danish material by Tauber (1981; see also Meik-

4 Material is from 1930s excavations at Arruda and Amoreira, but material for Moita may be from the 1960s (Lentaker pers. comm. 8.iii.2004), so there are certainly sampling problems related to the multiple excavations. A rereading of multiple reports on Moita excavations suggests the possibility that the layers containing mammalian bone were removed by bulldozers prior to excavation at Moita in the 1950s. 
lejohn et al. 1998). However, the full situation is quite complicated when sample variation and outliers are examined.

How do we explain outliers? Among the Mesolithic individuals we have one with an extremely high $\delta 15 \mathrm{~N}$ value (>16), Samouquiera H2, who consisted only of arms when excavated (Lubell, Jackes 1985). The individual showed bilateral arthritis in wrists and hands, especially marked on the right side. The body was buried close to Samouqueira $\mathrm{H} 1$ who had sustained a major fracture of the right humerus leading to an open infected wound and also had an infected wound of the right foot. Both individuals therefore could be suggested to have disabling trauma, a consequence of which is likely to be a way of life and a diet different from their Mesolithic fellows. In addition, there may be a form of burial different from that for able-bodied people. In the case of Samouqueira, we seem to have people who, in the months before their deaths, were separated from the rest of the population. No other human remains were found among the 286 faunal bones 5 (mostly Oryctolagus cunniculus) scattered among the marine bivalves, gastropods and fish covering this cliff-top site.

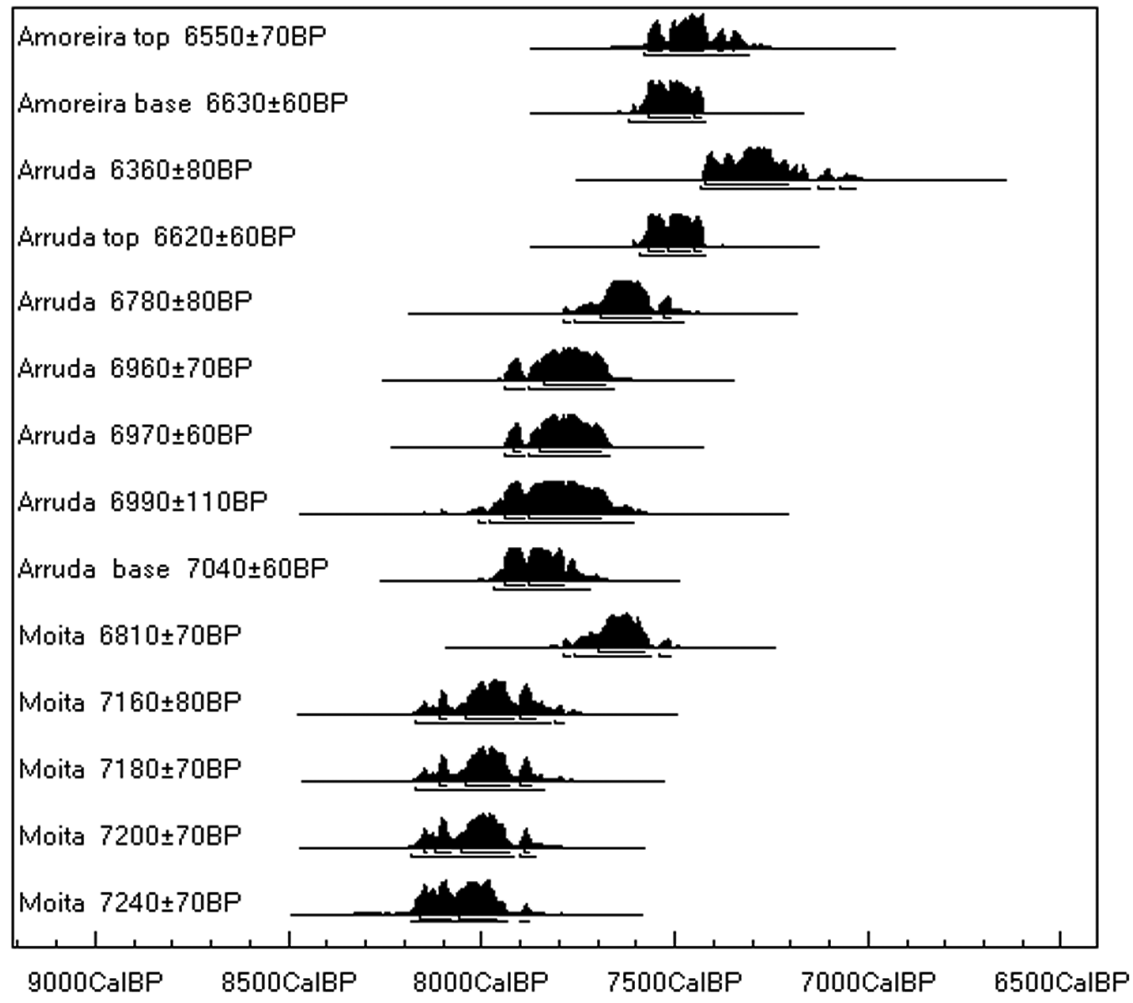

Fig. 3. Calibrated AMS ${ }^{14} \mathrm{C}$ dates directly on the human skeletal material (Lubell et al. 1994). New dates, identified as "top" and "base", from recent excavations at Amoreira and Arruda by Rolão and Roksandić (Roksandić in press). 1 and 2 standard deviations are shown beneath the probability curves (Bronk Ramsay 2002).
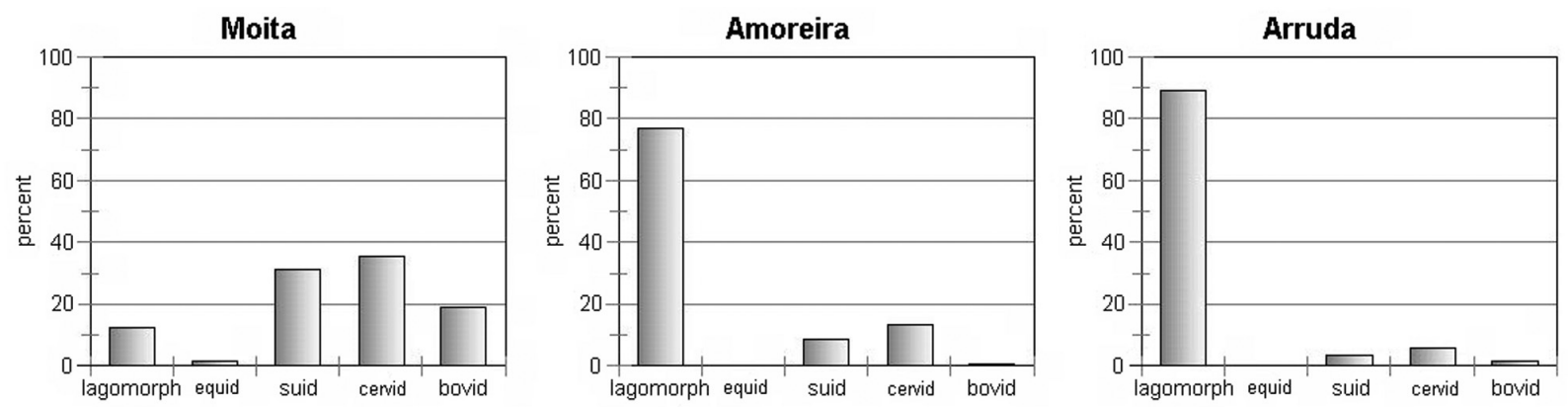

Fig. 4. Percentage representation among selected terrestrial mammals in the Muge collections of the Sala de Arqueologia e Pré-História Mendes Corrêa Museu de História Natural, Faculdade de Ciências Universidade do Porto (Lentaker 1991.254-255). The Moita material is, however, in the museum of the Servicos Geológicos de Portugal.

5 The exact number provided by Lentacker (pers. comm. 19. IX. 1986).

6 Since the site was an ossuary cave of disarticulated bone, we can say nothing more about this individual. Further analyses are now being undertaken on material from this cave. 


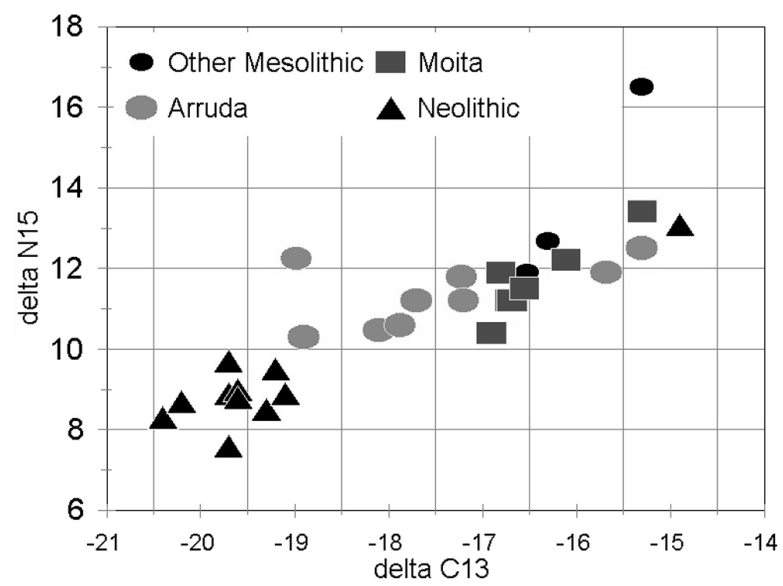

Fig. 5. Stable isotope values for Portugal. "Other Mesolithic" sites refers to Amoreira and to Samouqueira in the outlier position at the extreme marine pole of the diagram.

Arruda individual (N) is an outlier for the Arruda stable isotope distribution (Fig. 6), with a more marine based diet, and we know that he is exceptional for the Mesolithic population, with spinal changes that included osteoporotic collapse of T.10 and collapse and fusion of L.1 and L.2.

In the discussion above we proposed an initial interpretation from Figure 5 of a gradual shift from a marine to a terrestrial based diet. The conclusion is problematic when outliers are considered and especially when the dates for specific individuals are examined from the site of Arruda (Fig. 6). At the Neolithic "pole" to the left, marked by the most terrestrial shift, are Arruda A and D, individuals falling within the middle of the dated range for Arruda specimens (Fig. 7: individuals with probability ranges in grey) 7 . At the opposite Mesolithic "pole", the most marineshifted, are Arruda $\mathrm{N}$ and an undated sample from $20^{\text {th }}$ century excavations now being analyzed by Eugenia Cunha, University of Coimbra. Interestingly, Arruda $\mathrm{N}$ provided the youngest date in our Arruda time series at $6360 \mathrm{bp}$. As a result, there is evidence contrary to a clear temporal trend within Arruda, the site which may provide our longest occupation span. On the other hand, a possible interpretation of Arruda $\mathrm{N}$ stable isotopes would focus

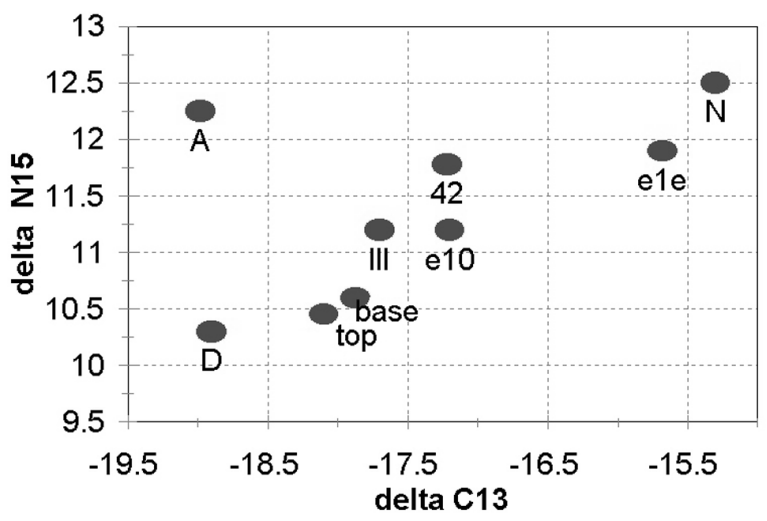

Fig. 6. Arruda stable isotopes. The two skeletons with " $e$ " designations are undated individuals now being studied at the University of Coimbra. The skeletons labelled "top" and "base" are from recent work at Arruda by Rolão and Roksandić (Roksandić in press).

on the date as illustrating a trend towards the reduction of tidewater influence in the Muge, and thus a reduction of estuarine resources. There may have been pressures for seasonal travel far down the Tagus River.

This interpretation of Arruda $\mathrm{N}$ depends on a manipulation of the date of this individual. Critical to the entire question of Muge Mesolithic dating is whether the reservoir effect is skewing the dates. The date alteration for a 100 percent marine diet entails an age offset of 253 \pm 29 years for Portugal (Monge Soares 1993). The results of calibration with a reservoir effect correction estimated from the stable isotope values for each individual are seen in Figure 8. At the top of the diagram we have dates estimated for individuals (like Arruda N) with stable isotope values indicating a large marine component in the diet. At

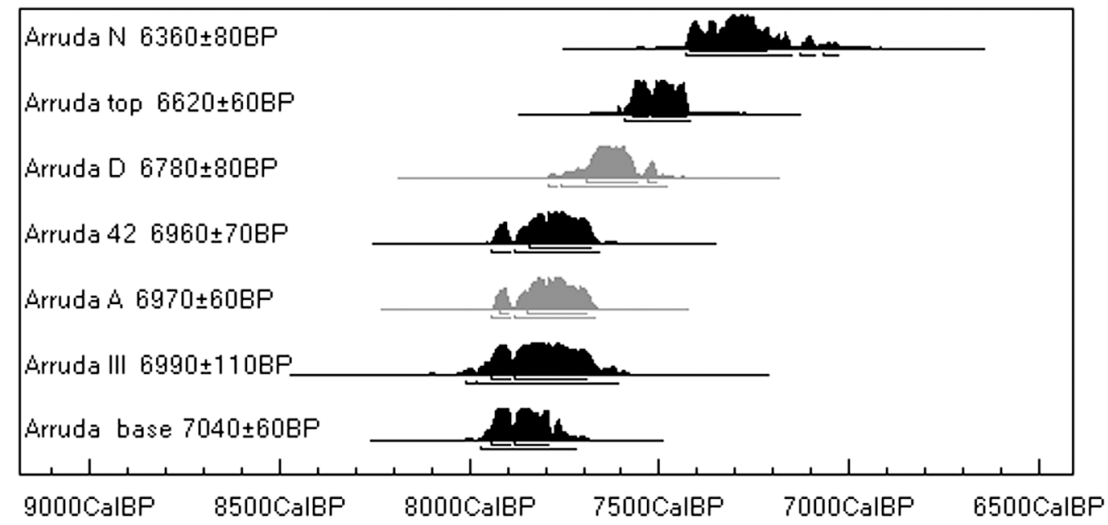

Fig. 7. Arruda dates (Lubell et al. 1994; Roksandić in press). The probability ranges in grey are individuals with low $813 \mathrm{C}$ values.

7 A single further Arruda date with $-19 \delta^{13} \mathrm{C}$ has been published (Cunha et al. 2003.185) which suggests that this pattern was established 600-800 years earlier, although the other Muge dates also published here are more congruent with previous information. 
the bottom are dates calibrated without a marine shift, because the dated samples are charcoal. Thus, from bottom to top of the diagram, we have increasing degrees of marine correction based on stable isotope figures, within the four groupings, showing no reservoir effect and marine corrections for 25 percent, 50 percent and 75 percent marine diet respectively (these are no more than rough estimates of the percentage of marine dietary component). The dates on human bone are from our own database, with the analyses undertaken by Henry Schwarcz (McMaster University) and by Isotrace (University of Toronto). No early Saclay dates are shown. It is of interest that, using reservoir effect corrections, Arruda N (together with Samouqueira, T0-130 6370 \pm 70 bp) is found to be a little younger than Mesolithic dates from Vidigal (Gx-14557 6030 \pm 180 bp charcoal) and Fiais (ICEN-141 $6180 \pm 110$ bp faunal bone), and equivalent in age to T0-953 $(5990 \pm 60$ bp, a human bone date from Casa da Moura), when the latter is calibrated with a 25 percent marine correction 8 . All these five dates calibrate as younger than the earliest Portuguese Neolithic date, 0xa-1033 $(6130 \pm 90 \mathrm{bp}$ on Ovis bone from Caldeirão). The conclusion is that an assumed gap in time and stable isotope values between the Mesolithic and Neolithic in Portugal may be an artifact derived from incomplete analyses.

\section{THE ARRUDA SKELETAL SAMPLE AS A BASE FOR DISCUSSION OF THE MESOLITHIC/NEOLI- THIC TRANSITION}

With the above discussion demonstrating Mesolithic heterogeneity and the difficulty of pinpointing a "moment of transition" to the Neolithic, we turn to the more specific question raised at the beginning of the paper, can the human skeletal data from the site of Arruda be used to develop a method for examination of the demography of the Mesolithic/Neolithic transition? We look at the history of the site and then at the extant skeletal sample that we have been working with for twenty years.

The site of Arruda is a large, roughly oval, midden on the north side of Muge River valley. At the edge of the valley flood plain, it was 95 by $40 \mathrm{~m}$, with a maximum depth of deposits of $5 \mathrm{~m}$ (Pereira da Costa 1865) or 100 by $60 \mathrm{~m}$, with about $7 \mathrm{~m}$ depth of deposit (Ribeiro 1880). The excavations by Pereira da Costa in 1863-1864, and by Roche and Veiga Ferreira in 1964 and 1965, identified four Mesolithic phases below the plough zone and disturbed soil, from top to bottom, levels A to D. Only half the mid-

8 Information on radiocarbon dates cited can be found at http://intarch.ac.uk/antiquity/jackes/dates.html 


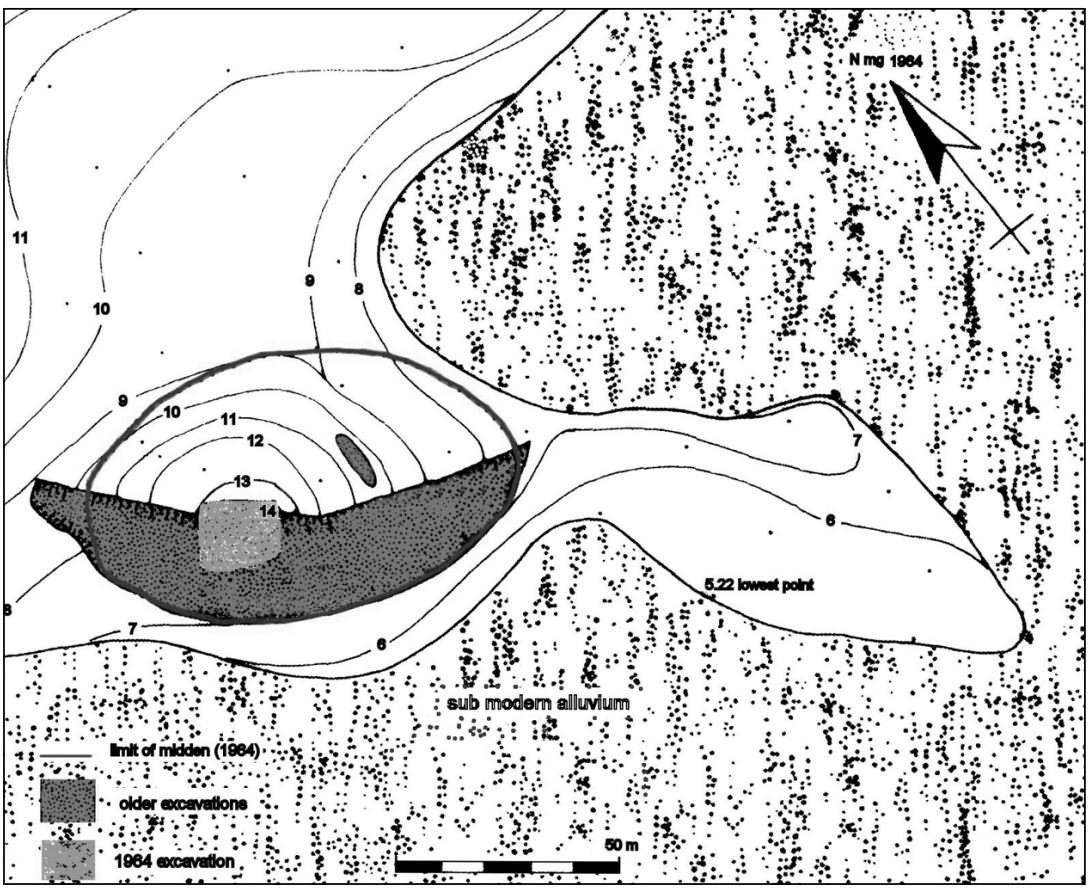

Fig. 9. Plan of Arruda, illustrating that about half of the midden has been excavated (modified after Cardoso, Rolão 1999/2000. Fig. 56).

den has been excavated to date (Fig. 9), and the skeletons from that half have an extremely convoluted excavation and curation history.

The initial excavation of the site, by F.A. Pereira da Costa of the Serviços Geológicos de Portugal, followed the discovery of several shell middens along the Muge by Carlos Ribeiro in 1863. This excavation apparently unearthed around 45 individuals mostly recovered from the base of the site in level D (Pereira da Costa 1865.7,13) (Fig. 10). It appears that the material from the original excavations was destroyed by fire in the last quarter of the $20^{\text {th }}$ cen-

\section{9; LeFèvre 1972) 10}

tury9. However, even in the late 1920s Vallois could not find the first skull, that of a male, from the 1860 s excavations, and considered it likely that it was already lost in the 1880s (Vallois 1930.353). He found only four other Arruda skulls in the Zoological Museum (ibid. 356) and it appears that he found no post-cranial remains whatsoever. A number of the finds were illustrated in the original publication (Pereira da Costa 1865) and we can confirm that the illustrated mandibles are not now in the Serviços Geológicos museum (Fig. 11). Studies of Arruda dentitions used only material in the Serviços Geológicos museum (Sueiro, Frazão

There is then a gap of fifteen years until the reopening of the site in 1880 associated with the International Prehistoric Anthropology and Archaeology Congress that was held in Lisbon in that year. Ribeiro opened up a further area of the site in order to provide a field trip for attendees at the Congress. This excavation again made it clear that the burials were not randomly distributed across the site (Fig. 12) but were grouped in the southwest part of the mound (Paula e Oliviera 1889.74). The skeletal material again came from a single level, presumably

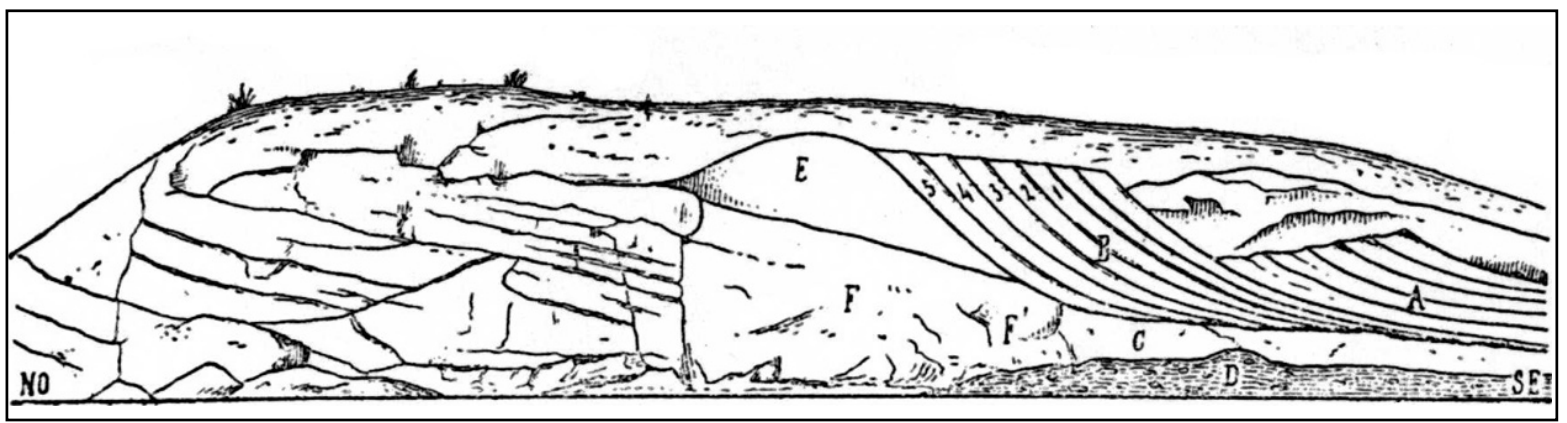

Fig. 10. Cross section of 1865 Arruda excavation showing localization of skeletons in one section of the basal layer of the midden - layer D on the lower right. The section goes from the north west (left) to the south east (right) and was first published (without a scale) by Pereira da Costa (1865.6.Fig. 2).

9 The material was stored at the Escola Politécnica which became the Faculty of Sciences of the University of Lisbon. On $18^{\text {th }}$ March, 1978 the Museu e Laboratório Zoológico e Antropológico da Universidade de Lisboa (Museu Bocage) was destroyed by fire.

10 This was true even though Sueiro had assisted Vallois in searching for material at the Faculty of Sciences museum where he worked in the 1920s (Vallois 1930.339). 
the same level as the material recovered in 1865 (Fig.13, level D). In addition, Ribeiro suggested that the skeletons were roughly aligned $(R i-$ beiro 1880.286). Pereira da Costa (1865.13) had in fact suggested that the skulls were oriented to the NW). The number of skeletons recovered at Arruda in 1880 is unclear: over 120 individuals were said to have been recovered jointly from Arruda and Moita (Ribeiro 1880. 285).

Again in the mid 1880s more excavations were undertaken, this time by Francisco de Paula e Oliviera, Ribeiro having died in November 1882. Further remains were recovered, in June 1884 "13 human skeletons, some in truth very damaged, of individuals of various ages", and in June 1885 "the remains of 39 individuals for the most part in a very good state of preservation"

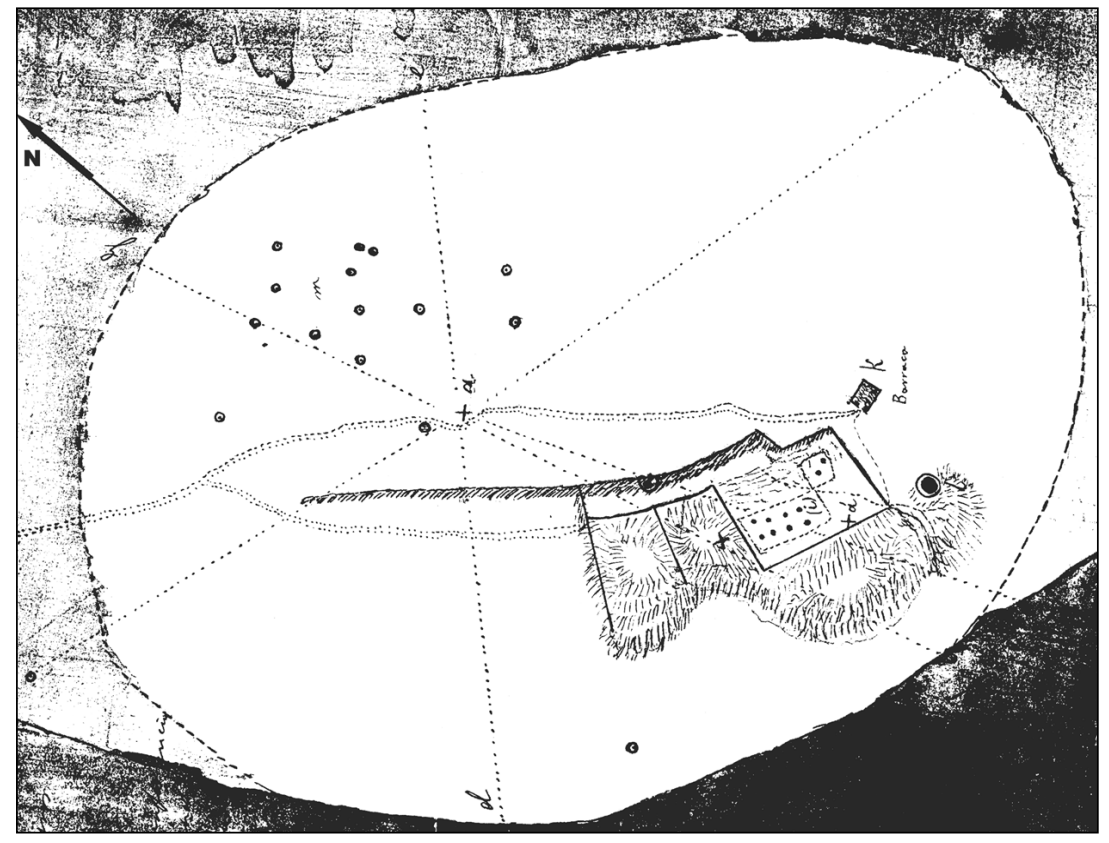

Fig. 12. After a plot by Carlos Ribeiro of the Arruda midden excavations in 1880. We are shown the locations of skeletons among the piles of back dirt. Another plot dated 15th April, 1880 detailing the location of 15 skeletons makes it clear that the points marking the skeletal finds here are extremely approximate. This and a number of other records of the 1880 excavations were found in the archives at Serviços Geológicos de Portugal and copied by David Lubell, 20th June 1989. It is believed that this material has now been deposited in the archives of Instituto Geologico e Mineiro, but has not been accessioned (Pedro Alvim pers. comm. 13. II. 2004).

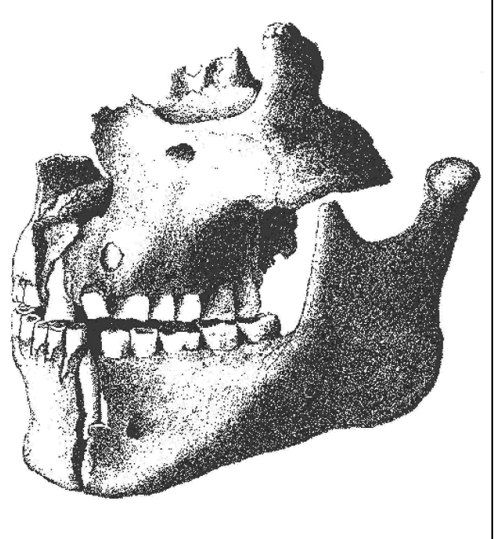

Fig. 11. Some of the Arruda skeletal material excavated in 1865 (selections from Plate I and Plate II Pereira da Costa 1865). The illustrated specimens are distinctive so that it can be confirmed that

(Paula e Oliviera 1889. 59). However, it is very likely that none of the 1885 skeletons came from Arruda. Paula e Oliviera indicated that "I barely got one skeleton in bad shape" (Paula e Oliviera 1889. 59) from Arruda11. Later excavations also recovered far fewer remains. The remains associated with the excavations of the 1930s were deposited in Porto and when examined by the authors were not in a condition to permit study. Most were removed en bloc and had not been cleaned and prepared, but original reports suggested 11 individuals had been excavated. Roche and Veiga Ferreira recovered only 13 graves in 1964 and 1965 and the finds have not been studied. As a result, any discussion of the human skeletal material from Arruda is largely concerned with finds recovered in the 1880s. In the late nineteenth century, it was believed that the Arruda skeletons stored in the Muge collection in Lisbon numbered no more than 41 individuals (Hervé 1899. 267).

11 A letter dated $4^{\text {th }}$ June 1885 from Paula e Oliviera to Nery Delgado indicates that all the human material excavated in 1885 is likely to have come from Moita (Alvim pers. comm. 13.II.2004), neither Arruda nor Amoreira having produced results. For further discussion see Alvim and Jackes in prep. 
The study of Arruda has presented logistical problems for the authors of this paper. Neither the full site nor the associated skeletal remains have ever been published in a single definitive study comparable to that of Moita (Ferembach 1974; Roche 1972). Meiklejohn first inventoried the collection in 1969 as part of an earlier study (Meiklejohn 1974). We both studied the material in 1985, and Jackes reexamined the collection during work at the Serviços Geológicos that extended from 1986 to 1989 . As part of the research reported here we have recently spent 3 months in a re-examination of the mandibles, using photographs taken by the two of us, records of detailed observations and measurements, radiographs and field notes.

The major problem is that, although the material has been consistently curated in the same facility at the museum of the Serviços Geológicos in Lisbon, the material has been mixed. Extensive examination of the historical records shows three different potential bases for this. The earliest may relate to the original conditions of burial. Perhaps these were not always the single inhumation burials that are usually inferred, a question raised in the early publications, but it is most likely that the grouping of burials led to disturbance of earlier by later inhumations, to the extent that the original report spoke of skeletal elements found "pell-mell" and "in the most bizarre positions imaginable" (Pereira da Costa 1865.15). A second potential source of mixing is at the original time of excavation and subsequent deposition in museums. The 1880 excavations involved the exposure of the burials considerably prior to the International Congress, and participants at the Congress were permitted full access to the burials during the field trip, so mixture may have occurred at that time. The materials excavated in the 1880 s were then subject to over 120 years of curation under circumstances such that mixture of material was almost inevitable. Individual bones were never labelled and the open drawer system (in place until we reorganized the material in closed boxes from 1984 to 1986) invited misplacement of bone. We thus have a situation where the material is curated as individual inhumations but many of these are not "individ- uals". One "individual" has 66 metatarsals, including 13 left second metatarsals and another includes nine right and six left clavicles 12 . Yet a third ("individual" $M$ ) has 41 separate maxillary and mandibular fragments actually representing 21 separate individuals.

The photographs from Arruda in 1880 (e.g. Fig. 13) give a reasonable sense of the distribution of the finds within a single level and they also help us understand that there were problems made obvious by the following quotations: "One sees also bones here and there, placed in confused heaps as if they had been gathered together once the flesh was gone; but in the majority of cases they are in their natural articulations..." (Cartailhac 1886.57) and "Because the bones were generally grouped according to their natural articulations, it is possible, most often, to collect separately those of each individual..." (Paula e Oliviera 1889. 72; our emphasis). The problems can also be seen in the plots from the 1964 excavation of Roche and Veiga Ferreira (Fig. 14). Whether the skeletons numbered 6,7 and 9 in this diagram represent two or three people could only be confirmed by detailed study.

The suite of problems stemming from the history of the site can be summarized as follows:

(1) In the 1860 s it was already obvious that there were "bones not belonging to the skeletons" (Pereira da Costa 1865.16,18) and that the complete ske-

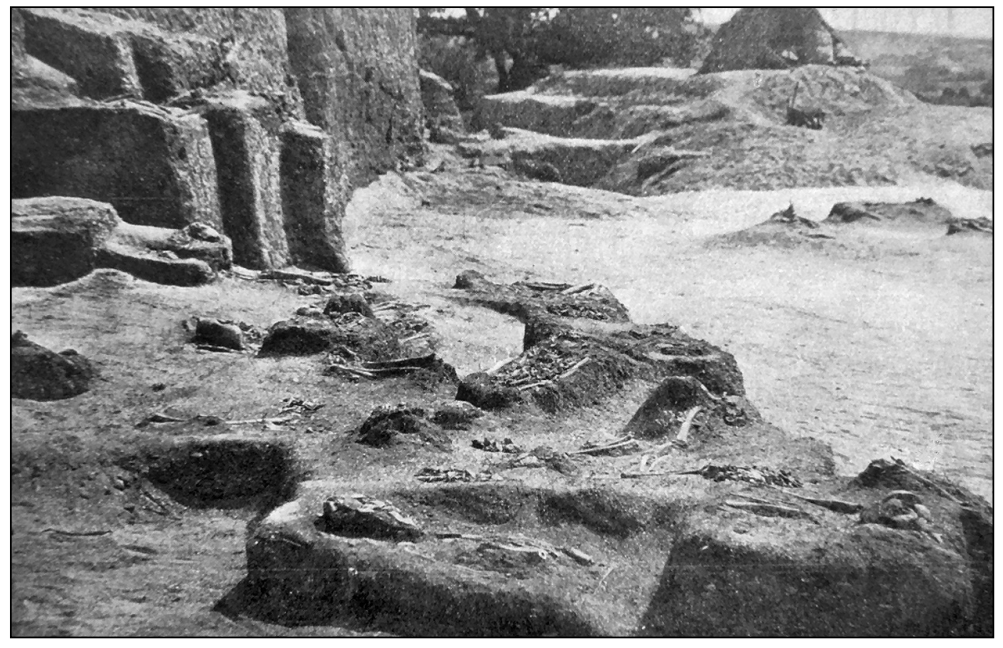

Fig. 13. One of two photographs of the 1880 Arruda skeletons known from various publications. This photograph appeared in 1908 (Anon. 1908). The view is towards the south east along the excavation face and across the skeletons marked schematically by dots in Figure 12.

12 These were unnumbered individuals, called TO and SH by our project. 
letons had, mixed among them, other bones (ibid. 18). Since no material from the 1860 s is extant, we can no longer judge the extent to which material was selectively retained.

2 However, it is clear from the descriptions that not all bones were kept in the 1880s: "...the number of human skeletons that were recovered, even leaving aside the bones which were abandoned because of their bad condition, is truly considerable." (Paula e Oliviera 1889.71, our emphasis).

(3) At the time of the study by Vallois there were 42 drawers of Arruda material in the Serviços Geológicos museum (these remained until the early 1980s), but parts of two or three indi-

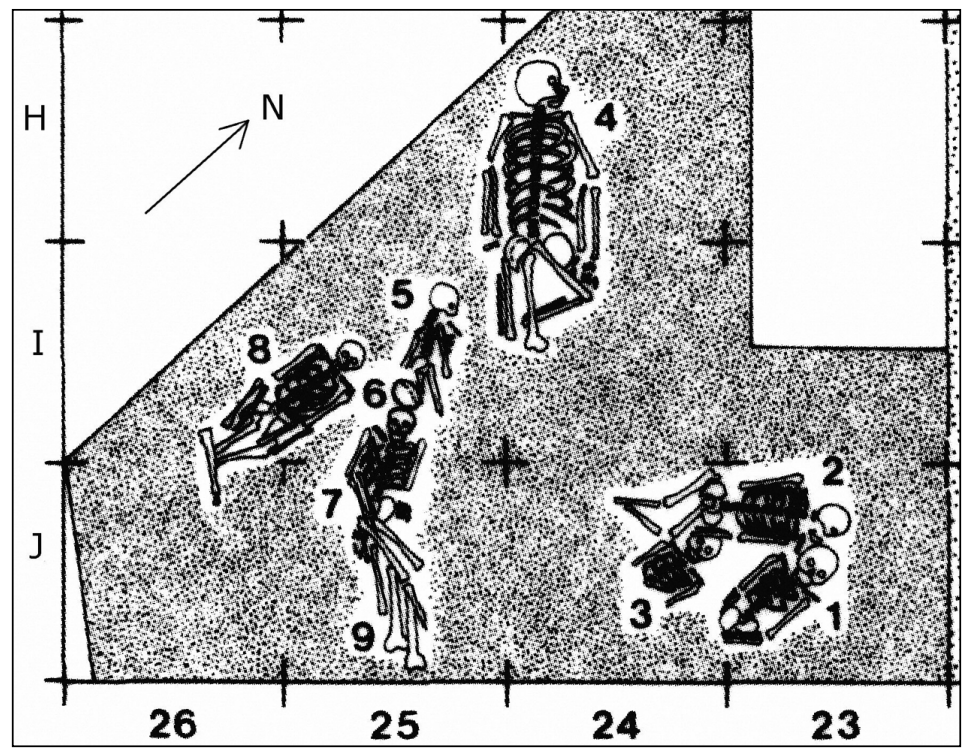

Fig. 14. After a plot from the 1964 Arruda excavation of Roche and Veiga Ferreira (Cardoso, Rolão 1999/2000.Fig. 57:227). viduals were found in some drawers (Vallois 1930). Mixing was already a problem. Vallois also stated that he could not find a skull, a female, which had been deposited in the Serviços Geológicos museum. Vallois saw 20 to 25 Arruda skulls and some further cranial fragments (ibid. 340). He also studied some postcranial material, writing that he hoped someone would undertake the work of trying to redress the errors and reconstruct the bones (ibid. 365). Vallois considered that there was no possibility of matching skulls with postcrania (ibid. 364).

4 The material recovered in the excavations of the 1930s was sent to the Instituto de Antropologia Mendes Corrêa, Universidade do Porto. We attempted, independently, to inventory these materials: Meiklejohn in 1969 and Jackes in 1984. Although 10 or 11 individuals were said to be present (Cardoso, Rolão 1999/2000. 172-179), fire and subsequent flooding in 1974 (Huet Baçelar pers. comm.: August 1984) have complicated matters. When inventoried in 1984, it was clear that labels had been lost: most material at the Mendes Corrêa Institute was from Moita so that it could be checked against an earlier Moita inventory (Ferembach 1974), and there was obvious confusion after the fire. Of four Arruda indi- viduals inventoried in 1969, one child from $1933^{13}$ and three adults from 1937 can be clearly recognized in the 1984 inventory. In 1969 the adults had had skulls and mandibles: the skulls and mandibles were not found in 1984. In addition, other material was found with Arruda labels in 1984, including a child aged about 7 and a child aged about 13, both with dentition. Other material was unlabelled, and it could have come from either Arruda or Amoreira ${ }^{14}$.

(5 In 1964 and 1965 Roche and Veiga Ferreira excavated 13 "skeletons", apparently from the basal levels of Arruda (Newell et al. 1979, based on conversations with Roche in Paris in 1978). These had been placed in a rented storeroom separate from the Serviços Geológicos premises, and there was apparently no recollection of this, either in 1969 or in the period 1983-1989. They were rediscovered in 2000, and therefore have not been examined in detail 15 .

6 By the 1980's, when we began our work at the Serviços Geológicos, there was obvious mixing among individuals in the drawers. There was also loss of identification due to mixture and loss of labels ${ }^{16}$. In some cases material from a single individual had been dispersed, some elements being kept

13 A limited amount of work was done at Arruda in 1933 (Cardoso, Rolão 1999/2000.170).

14 Lentacker (pers. comm. 8.III.2004) confirms that problems caused by the fire were exacerbated when some of the faunal collection labels were destroyed by the water used to extinguish the fire. Meiklejohn worked on human material in a storage area which was later damaged by the fire. By 1984 this material was widely dispersed throughout the building.

15 All dental elements were photographed in detail by David Lubell (23 April, 2002).

16 Individual bones were never labelled with specimen numbers. Some, but not all, crania and mandibles were labelled. Detailed notes kept by the authors allowed us to track mixing which occurred during the visits of one or two other researchers even with in the short period 1984-1986. Further mixing had occurred by April, 2002 (Lubell pers. comm.). 
in glass cases for display. The absence of any previously published inventory complicates any attempt to provide a catalogue raisonée. However, comparison with the similar problems in the Moita collection is illuminating. Ferembach prepared an apparently complete inventory of Moita prior to 1965 (Ferembach 1974). The same material was independently inventoried by Meiklejohn in 1969, without knowledge of Ferembach's results. When both of us did a third inventory in 1984 and 1985, the discrepancies became apparent. While some of the descriptions were in agreement for all three inventories, all other possible agreements and discrepancies were observed, the most discrepant being totally different number associations in the three inventories. In addition it became clear that no inventory prior to 1984 had involved full cleaning of the material. We cleaned material in 1984 and 1985 that could not previously have been inventoried accurately. An example of this can be seen in the reported number of Moita teeth: Ferembach (1974) reports only 428 teeth, whereas preliminary estimates from the inventory of 1984 and 1985 list 889 teeth (Meiklejohn et al. 1988; Meiklejohn, Zvelebil 1991).

\section{ARRUDA AND CASA DA MOURA: HOW CAN WE COMPARE THEM?}

In studying the Portuguese Mesolithic/Neolithic transition we must compare Casa da Moura, a Neolithic ossuary burial cave (by definition a site with disarticulated and mixed individuals), with a Mesolithic site, traditionally regarded as having individual inflesh burials. Even without the problems of Arruda, for which questions surround the burial practices, the excavations and the post-excavation history of the material, we would need careful consideration of methods in dealing with samples for demographic analysis. This is the core problem set up in the introduction to the paper and we will use mandibular counts as a basis for discussion of demographic questions at the Mesolithic to Neolithic transition.

Palaeodemography demands exceptional care. In making statements based on inadequate and possibly incomplete samples, covering periods of time which are, at best, partially defined and generally too long for satisfactory demographic study, anything less than extreme caution is injudicious. To compare skeletal samples from different sites, it is necessary to use comparable methods of analysis for each site; methods of calculating the numbers of individuals must be comparable; methods of age assessment of both adults and subadults must be comparable, because different methods give different results (Jackes 1985). Consistency is critical.

Taphonomic studies show that mandibles provide the highest number of elements in most skeletal collections, whether human or non-human. Use of mandibles allows for the maximum estimate of numbers in a site, different in many ways from the "minimum number of individuals" (MNI). Mandibles are more sensitive to details than other skeletal elements, carrying a great deal of information, and the use of mandibles also allows refitting even when clean reconstructable breaks are absent.

Delgado (1867.46), in writing about Casa da Mou$\mathrm{ra}$, recognized that the number of mandibles would give a much higher count of individuals than would the number of skulls, whole or fragmented, and especially the number of maxillae. But in sites where teeth are not retained in the alveoli, it is necessary to enquire also: 1 . whether mandibular teeth are more often retained in the jaws and 2 . whether mandibular teeth are more likely to be represented in the deposits than maxillary teeth, whether in situ in alveoli or loose. Neolithic sites contain many loose teeth and it becomes clear that more teeth are retained in the mandibles than in the maxillae. Figure 15 , in which loose teeth are plotted as a percentage of total teeth, shows that fewer mandibular teeth are found loose in all tooth classes. As a result, this means that the lower teeth can be studied in more

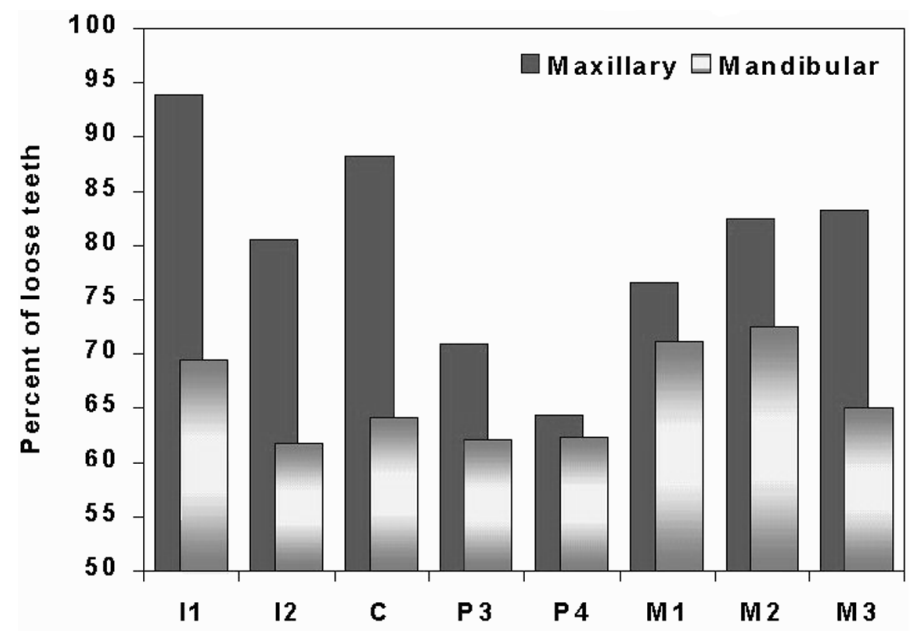

Fig. 15. Percent of loose teeth in Casa da Moura, comparison of maxillary and mandibular dentitions (after Jackes, Lubell 1995.Fig. 8a). 
detail, that their identification is more certain, and that fewer will be left unrecovered from the back dirt piles of an excavation. In fact, Delgado clearly stated that "maxillae are very rare while on the contrary mandibles are very abundant, and above all mandibular teeth..." (1867.46) and drew attention to parallel findings by Lartet with regard to non-human remains at Aurignac. This pattern is now well documented in vertebrate taphonomy.

Furthermore, we have concentrated on molar teeth because, in Neolithic sites, up to 30 percent more molars are preserved than the next most common tooth types (premolars and canines). This is true of other Portuguese Neolithic sites that we have studied, besides Casa da Moura (and see e.g. Jackes, Lubell 1995. Fig 9 for comparison with a site studied independently, though using the same dental identification methodology). Figure 16 shows the ratio of the observed to the expected number of teeth based on the MNI for Casa da Moura. If all teeth for the total MNI were present, the ratio shown on the y axis would be 1.0: the second mandibular molar representation approaches an observed versus expected ratio of 1.0.

Figure 16 reminds us that we need to look at more than the intact teeth that have been recovered and

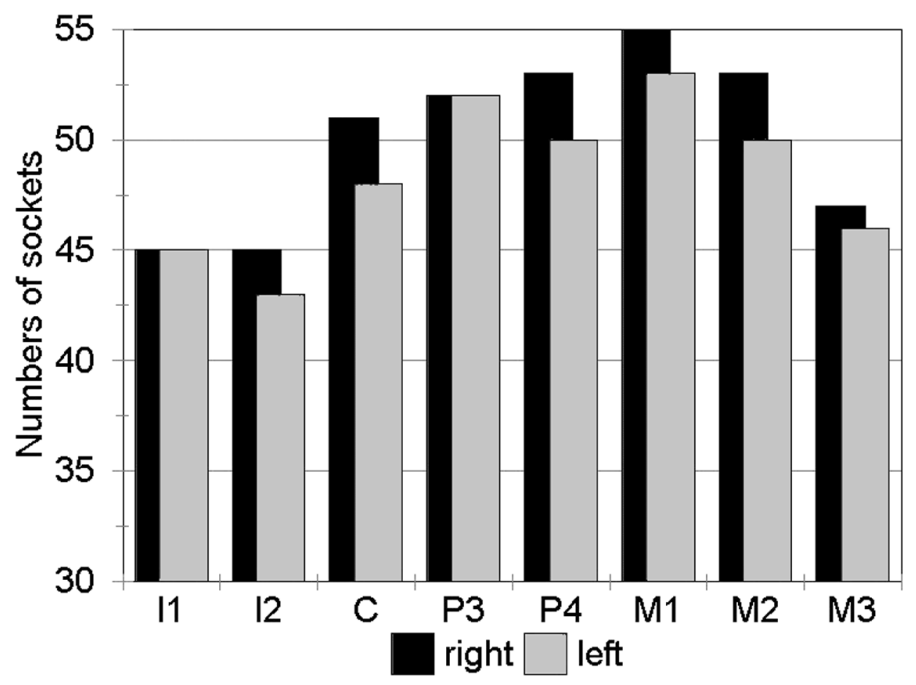

Fig. 17. Classic MNI study of Arruda mandibular sockets allows us to examine not just intact teeth, but also antemortem tooth loss and postmortem tooth loss. MNI based on Arruda adult mandibles in the Serviços Geológicos, Lisbon 1984-1989. thus can be directly studied. We need to consider teeth that have been lost pre-mortem, from pathology or accident 17 ; thus, the more alveolar sockets, the better. Unfortunately, such an approach means that the estimated number of older adults based on a sample partially made up of loose teeth will always be slightly wrong. The estimate of the ratio of subadults to adults may be too high for the Neolithic sites with many loose teeth, because information on premortem tooth loss may be gone. This must be emphasised - it is very possible that the number of older adults in Neolithic sites will be underestimated and the effect of this will be to give an apparent increase to the rate of fertility in the Neolithic in comparison with the Mesolithic.

For Casa da Moura we obtain an MNI of 302 individuals with adult molars, derived from both the right lower M1 and the left lower M2. This is based on teeth with root development at least half completed or teeth fully erupted.

Figure 17 provides a classic MNI type study for Arruda. This figure illustrates sockets so that we can examine not just intact teeth, but also both antemortem and postmortem tooth loss (in this case loose teeth are not involved, so that empty sockets can be taken into account). We can immediately see that the 42 skeletons that were assessed as the total number of all ages from infants to adults between 1880 and the late 1920s when Vallois (1930) looked at them, can-

17 Naturally, sockets that have lost teeth postmortem cannot be counted, since the shed teeth will be present in the deposits and must be assumed to have been counted. 
not encompass the full number of individuals represented in the Serviços Geológicos museum. The figure clearly indicates that the MNI for adults alone must be around 55, based on the value for $\mathrm{RM}_{1}$. However, the use of mandibles allows one to go beyond the classic MNI count for a site, since MNI depends on the side with the highest count.

Our results are based on the reconciliation of three different inventories undertaken by the two of us, together and independently, from 1984 to 1989 . Our records also include photographs, details of tooth status, attrition, pathology, measurements, notes and reviews of the refitting of mandibular fragments found in separate drawers and glass cases. We have obtained a remarkably consistent picture regarding the representation of sides and tooth types, based on 85 mandibular fragments aged 15 and above (including intact and fractured teeth, empty sockets, cases of premortem tooth loss and agenesis). And the use of mandibles clearly produces a result that is higher than the just derived MNI of 55 adults (Fig. 17).

Primary work had in fact already shown us that 55 was not the maximum number of adult individuals. In 1986, 62 mandibles of individuals judged to be adults over age 15 were seriated (Figs. 18a, b, c). Furthermore, there were at least 8 other mandibles in the collection, mostly associated with skulls in the display cases in the museum.

Of those under 15 years of age, 25 were initially seriated (Fig. 19), to which six were added from among the material on display in the museum. The estimate of subadults has some questionable individuals - perinatal infants who are often represented in the collection by long bones rather than mandibles. Our methodology takes account of these infants despite the absence of mandibles. But, in fact, the

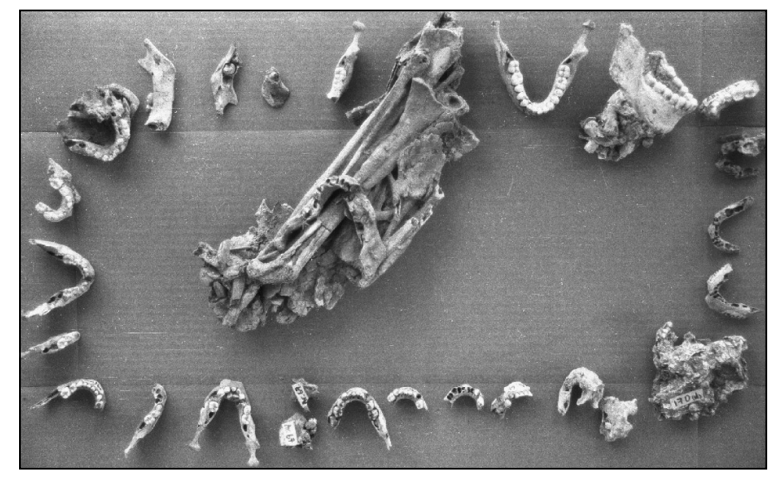

Fig. 19. Seriation of subadults based on eruption sequence and attrition.
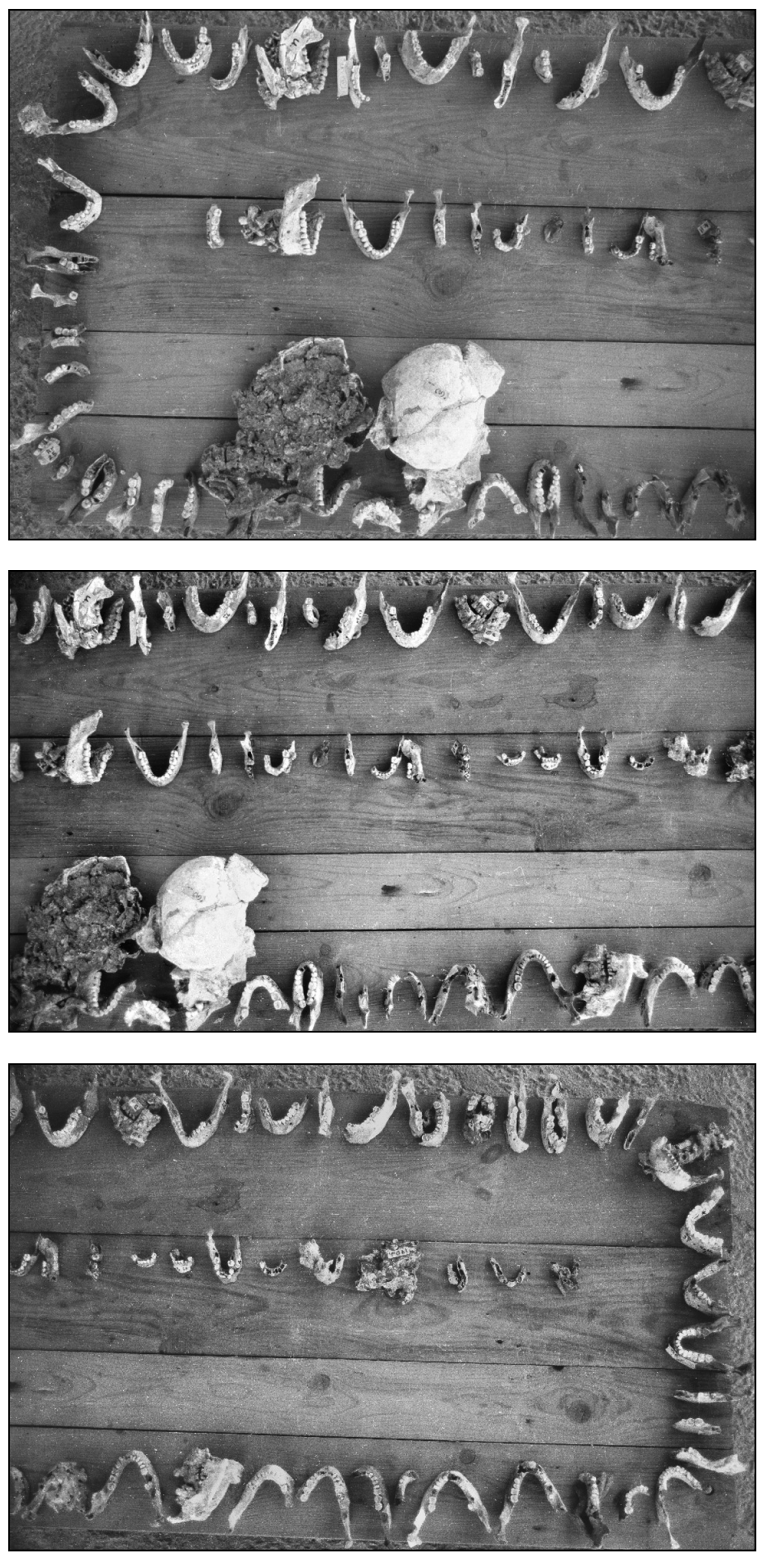

Fig. 18 a, b, c. Seriation of Arruda mandibles 15 years of age and older, based primarily on attrition with attention to pathology and preservation. This allowed reconstruction of separated mandibular fragments (some juveniles are shown in the centre of the images).

demographic method we use ignores children under 5 , because infants and young children are markedly under-represented in Neolithic skeletal collections, and are generally poorly preserved. Thus the uncertainty surrounding young children is not critical.

The seriation of mandibular secondary teeth (Figs. 18 and 19) was based on observation of wear of the three lower molars, with secondary consideration of more anterior teeth. The initial seriation was visual, and undertaken by several people over a number of days, the placement of each fragment 
being discussed. The same process had been previously undertaken on Moita adult mandibles. Arruda wear seems slightly reduced compared to what we had observed in the Moita series, and the Casa da Moura attrition is reduced from Arruda (see e.g. Lubell et al. 1994). However, the same sequence of attrition stages can be used: it covers eight wear levels, from 1, where the molar tooth has only just come into occlusion, to 8 , with a rim on less than three sides, or all enamel removed and wear progressing down onto the tooth root (see Lubell et al. 1989 for details). Because Casa da Moura wear is slower than in the Mesolithic, more attention was paid to variations within wear levels. For example, wear level 3 lasted longer within a person's adult life, and it was possible to discern gradations within level 3 that were not obvious in the Mesolithic, especially with Moita (Jackes 1992). Finally, the Arruda subadults were seriated separately (Fig. 19) ${ }^{18}$.

The seriation process provided other benefits. Some identification problems were sorted out. In 1986 the process allowed the refitting of nine mandibles across drawers, that is, two or three fragments of each of nine mandibles were found dispersed over separate drawers. The drawer with label "M" was particularly problematic. It contained 13 maxilla fragments, 21 mandibular fragments and 27 loose teeth in 1984 . There were actually 21 individuals represented by the $\mathrm{M}$ mandibular fragments. The $\mathrm{R}$ series identified and reported by LeFèvre (1972) remains unidentifiable, but may have included material now labelled "M".

As noted above it was necessary to add further individuals to the visual seriation. These included mandibles in the display cases in Lisbon that could not be removed for study with the seriated specimens. Post facto seriation was possible though a variety of means that included photographs, measurements of the cemento-enamel junction height above the alveolar margin, and attrition scores. To the mandibles on museum display we can now add the material excavated by Roche and Veiga Ferreira in 1964, stored away and apparently forgotten. None of it was available in 1969 or in the 1980s. The dentitions were photographed by David Lubell and from those photographs attrition and status can be accurately recorded, at least to the level of comparison with material previously studied (Fig. 20 ). None of the 1964 mandibles match with any of the 1880s mandibles. This material represents eight new individuals, four under 18 and four over 18. Veiga Ferreira had actually plotted 13 individuals (Cardoso, Rolão 1999/2000.Fig. 57:227), but half of them were incomplete, so it is not surprising that we do not have 13 full individuals.

The age of subadults is both very important and problematic. In the demographic approach used, it is important that we know which individuals are under 5 and which are 5 and over. Radiographs help with the question but a complete reassessment of dental age in Mesolithic and Neolithic Portuguese children is being undertaken because there are some questions about the timing of eruption sequence events. Figure 21 shows the type of information used in this study. Arruda M (41) is probably under 5 years of age, with the adult first molar unerupted, and the second premolar ( $\mathrm{P} 4)$ crown not yet visible below the 2nd deciduous molar. In Arruda 176, already 5 years of age, the first molar is advancing towards eruption, the premolar crowns are apparent, the second molar is forming, and the roots of the central incisors are developing.

We arrive at a maximum estimate of 71 adults over 15 years of age present in 1984-1989 in the collection of the Serviços Geológicos, Lisbon. Adding subadults and the eight newly found individuals recovered from storage in 2000 , the total is 105 , based on mandibles.

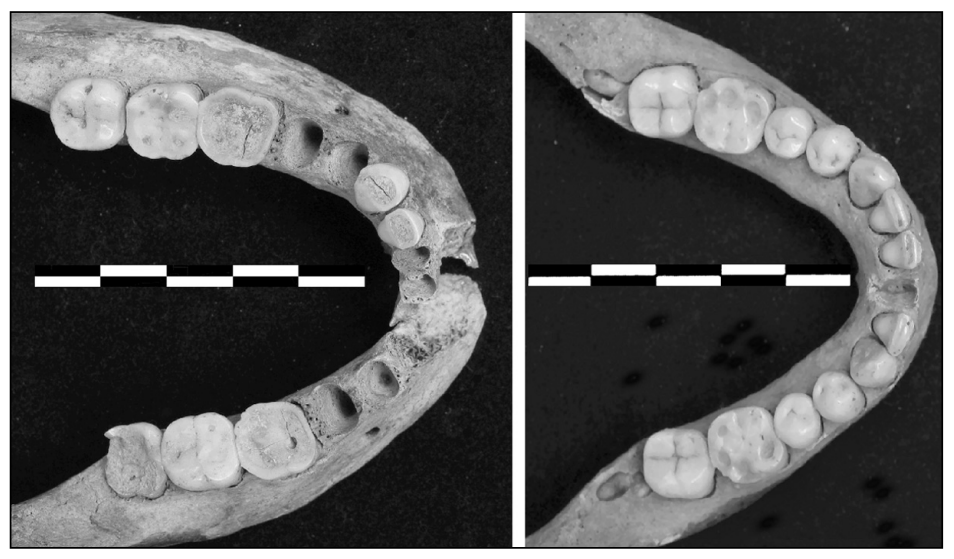

Fig. 20. Examples of mandibles from the 1964 Arruda excavations now in the Serviços Geologicos, Lisbon: Sk 17 8.2.311 on the right, Sk 18 on the left. Detailed colour photography (David Lubell) allows confirmation that none of this material was in the collections in the 1980s.

18 Examine the child still partially en bloc: in a North American site the interpretation would be that secondary bundle burials were present. 

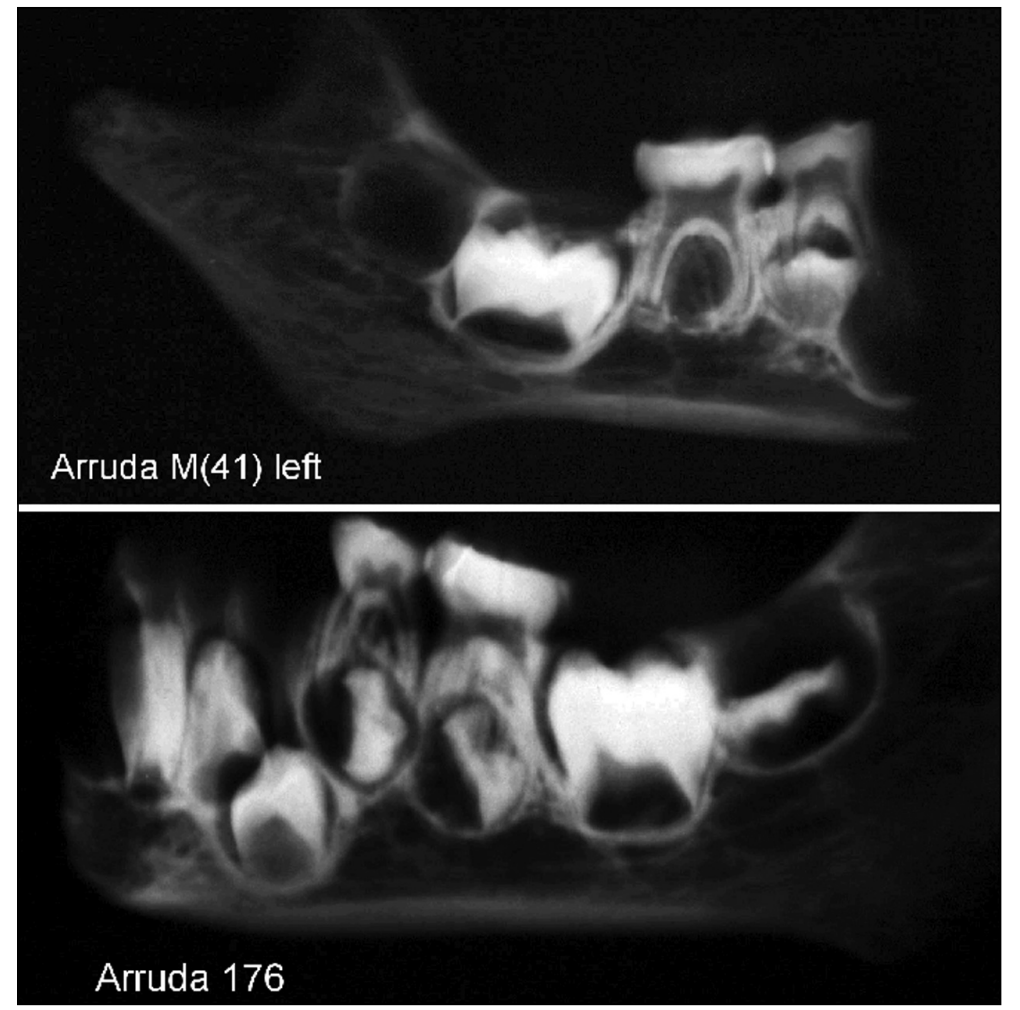

Fig. 21. Radiographs of juvenile dentitions: Arruda 176 (x-ray Sintra 90-2.VIII.86) and Arruda M(41) (x-ray Sintra PMD.1-5.XI.85).

Our sample is shown in Table 1, with totals of 77 for Moita, 105 for Arruda and 340 for Casa da Moura. The previous publication of Casa da Moura (Meiklejohn et al. 1997) was based on an MNI of the loose right lower molars. Here we include a more complete set of data, including loose and in situ right lower molars, together with correction for premortem tooth loss (Jackes 1998; Arnaiz-Villena, Lubell 2000). The Moita sample includes those mandibles inventoried in Porto in 1984. There were a number of very young children in the Porto collection: the fact that they could not be seriated visually with the other Moita material is less important since our methodology ignores those under 5 years of age 19 .

\section{COMPARING ARRUDA, MOITA AND CASA DA MOURA}

The results of our study of the mandibles from Arruda, Moita, and Casa da Moura (Fig. 22) have implications for research on the demography of the
Mesolithic/Neolithic transition. In order to provide a context, we have a large database of archaeological sites that have sample sizes of at least $100^{20}$. To that we have added historical data, for example some of the excellent French and French Canadian historical demographers' analyses of parish records (e.g. Charbonneau 1970), allowing for an understanding of the biological realities underlying demographic data something that has not always been considered by palaeodemographers (Jackes 1994). The plotted variables are the mean subadult mortality quotient (probability of death age 5-19, MCM or mean childhood mortality) and the ratio of children between 5 and 15 years to adults 25 and over. This approach to palaeodemography, the ratio of children to adults, was first suggested by Angel (1969), and has been systematized over a number of years through the work of Bocquet-Appel and Masset (e.g. Bocquet and Masset 1977). We use Bocquet-Appel's index of juvenility, which we term the J:A. For further discussion of the approach see Jackes (e.g. 1992; 2000; Meiklejohn et al. 1997).

To provide further external control we have used the model data of Coale and Demeny (1983) and the United Nations (1982). These data are marked on Figure 22 as representing populations that are

\begin{tabular}{cccc}
$\begin{array}{c}\text { Age } \\
\text { Categories }\end{array}$ & Moita & Arruda & $\begin{array}{c}\text { Casa } \\
\text { da Moura }\end{array}$ \\
\hline $0-4$ & 14 & 17 & 42 \\
\hline $5-9$ & 6 & 9 & 31 \\
\hline $10-14$ & 1 & 5 & 33 \\
\hline $15-19$ & 3 & 4 & 18 \\
\hline $20-24$ & 8 & 8 & 64 \\
\hline $25+$ & 45 & 62 & 152 \\
\hline Total & 77 & 105 & 340
\end{tabular}

Tab. 1. Demographic data used in the analysis: age at death distributions.

19 Note that the Arruda material that was in the Mendes Corrêa Institute in Porto, now being studied by Eugénia Cunha at the Institute of Anthropology, University of Coimbra, is not included. This is because of questions arising from differences between the inventories of 1969 (Meiklejohn) and 1984 (Jackes and Huet Baçelar) and on what was destroyed in the 1974 fire/flood. A complete reassessment of Moita material is now being undertaken (Jackes and Meiklejohn in prep.), and it is to be noted that our publications on Moita have sample sizes varying from 77 to 79 in advance of this reassessment.

20 The Iron Gorge (Djerdap) samples of Jackes et al. in press are not included. 
stationary, increasing or decreasing. The archaeological and historical data fall comfortably close to the model data: in those cases where the archaeological sites fall far from the expected, we can suspect or demonstrate sample problems (biases which might result from site chronology questions, age assessment error, partial excavation, preferential burial etc.).

The diagram includes the full curve for populations that fall within the limits of reasonable demographic interpretation. As discussed elsewhere (Jackes 1994), the J:A ratio axis also provides a proxy measure for fertility. Populations at the upper right hand corner of Figure 22 would represent some of the highest recorded examples of natural human fertility. Some rare and exceptional archaeological populations do in fact provide calculated values beyond this apparent limit (e.g., Nea Nikomedia, Angel 1971). It seems likely that if they are to be interpreted as representing something other than samples unsuitable for demographic analysis by reason of their small size, they can be understood to illustrate exceptional circumstances. For example, one is a site in which there is ethno-historical evidence, not of high fertility, expected at the high end of the graph, but of high mortality associated with an influx of refugees from war and famine, preferentially of women and chil-

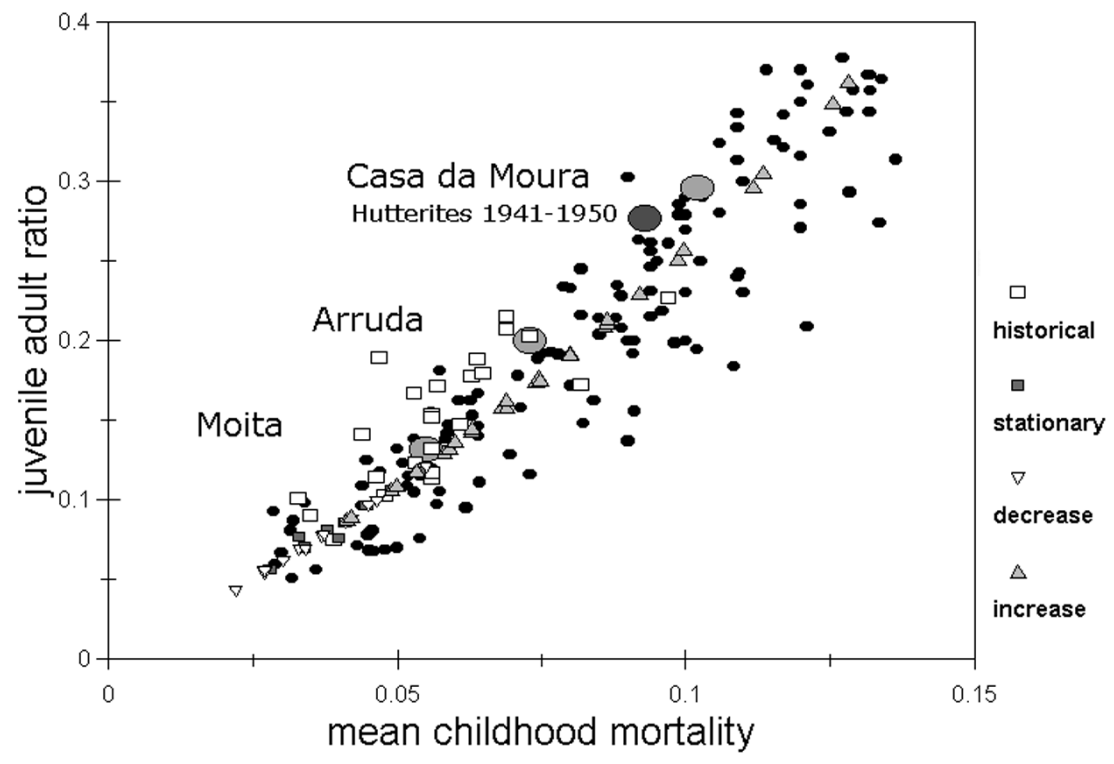

Fig. 22. Archaeological data, model data (Coale, Demeny 1983 West 1-10 increasing/decreasing/stationary and United Nations 1982) and historical samples provide the context for interpretation of information on the demography of Moita, Arruda and Casa da Moura. The Hutterite age at death distribution for the period 1941- 1950 (Eaton, Mayer 1953.238) provides the test for the method. dren (Jackes 2000b). Another is of freed slaves returned to Liberia in the $19^{\text {th }}$ century (1820-1843), a situation where young adults and children made up the bulk of the population (McDaniel 1992). The total fertility (henceforth TF) calculated for the Liberian emigrants from the US would provide values far beyond any possible human biological capacity for child-bearing, nearly 14 times higher than the actual Liberian TF rate at the end of the $20^{\text {th }}$ century.

In fact, the high end (at the upper right) of Figure 22 gives a total fertility estimate of about 12 . The average woman in such a society would, between 15 and 45 years of age, have 12 live born children - an acceptable type of figure for maximum "natural fertility". To assume that all women under a "natural fertility" regime 21 will produce, say, 20 children is not reasonable: it is most likely to occur under unusual circumstances, for example, when an epidemic has killed all the children in a family and a "replacement family" is achieved. But it is not the rule for the average woman. Examples of immigrant populations that did not practice contraception and emphasized child bearing (e.g. Mormons and the Quaker immigrants to the north east coast of North America) never reached such figures. The best data on "natural fertility" comes from North American Hutterites early in the $20^{\text {th }}$ century, suggesting 12 or 13 as the upper limit of TF. That the Hutterites had some limits on childbearing - some restrictions on sexual activity - is clear; nonetheless such an upper limit for TF is reasonable in the face of known social and biological constraints on human fertility. Coale's Index of marital fertility is a basic demographic value by which the Hutterites of 1921 to 1930 are taken to represent the maximum potential level of childbearing within marriage, exceeded only under rare and unusual conditions. The figure given is 12.4 children.

We must emphasize that we are talking here about the number of children possible under some circumstances

21 One not practising contraception. 
and that - in order to make comparisons - we are using a theoretical figure that may overestimate actual fertility. It is important to note that not all women in a population will have 12 children and that such a value for TF is, in fact, highly unusual. We are discussing a demographic parameter, the average number of live born children per woman in a population. Not all women are equally fertile, foetal loss occurs, some husbands are sterile, not all women marry, not all marry young and are continuously sexually active from age 15 to age 45 , not all women survive to menopause (see Jackes et al. in press; Jackes 1994 for discussion on the factors limiting fertility). Even French Canadian first settlers, few women though there were and with a strong incentive for large families, had a TF of around only eight (derived from data in Charbonneau 1970). Much of premodern western Europe, before antibiotics and with some crude contraception, relatively late marriage and with a less than $100 \%$ marriage rate, probably had a general population TF rate of well below eight. The Canadian Iroquoians were noted by the first Europeans who lived with them as having few children (Jackes 1994), perhaps five as a maximum (similar to Moita, and maybe to the total Iron Gates Mesolithic (see Jackes et al. in press)).

Stationary and decreasing populations fall at the lower left (Fig. 22), with Moita just at the upper end of stationary limits. In contrast, Arruda has already gone beyond that, and Casa da Moura would be beyond that again, firmly within the group of increasing populations. The values derived from the Hutterite age at death distribution for the period 19411950 (Eaton and Mayer 1953.238) fall close to Casa da Moura. Remember, however, that Casa da Moura, especially, has an inbuilt error within it. Because we do not have a full understanding of the number of old people who had lost their teeth premortem, because of the problem of loose teeth and destroyed mandibles, we must assume that there were actually more adults than we have shown here. Casa da Moura would probably fall a little lower on the curve, closer to 0.25 on the J:A (y) axis than its current position of ca 0.30 .
In Figure 23 we have a loess line (a local regression based fit line) derived from the fertility rates associated with the series of Coale and Demeny model tables we have used. The J:A ratio is again on the $y$ axis. The $\mathrm{x}$ axis now represents the TF rate. On the line we have added two points shown in black. The point to the lower left represents Nancy Howell's work on the Dobe !Kung (Howell 1979), with a TF estimate of just under four children derived from the J:A of the age at death distribution. This accords with Howell's own estimate of 4.3 for the period from 1963-1973. Note the position of the Hutterite estimate of nine for the TF rate estimated by regression from the age at death distribution J:A for the period 1941-1950 (Eaton and Mayer 1953.238, ages redistributed into standard age units). Summing the age specific fertility rates of all Hutterite women of reproductive age between 1936 and 1940 gives a TF rate of 9.4, and for 1946 and 1950 the TF value was 8.1 (Eaton and Mayer 1953.227). It is then very reasonable to estimate nine as the overall TF value to associate with those who died between 1941 and 1950.

Thus our Figure 23 is tied to some sort of reality, but there are caveats. Firstly, the sex ratio is assumed, for purposes of discussion, to be 1:1. The model populations from which this is derived actually have a slightly lower TF. Secondly, Moita sample size is not 
really adequate. Other problems have been laid out. Moita requires further consideration and has not been finalized. With Arruda we have the issue of partial excavation; some of the skeletons were lost; most skeletons have been mixed since excavation. With Casa da Moura we have a burial cave with multiple mixed disarticulated skeletons, smashed bones and skulls, and thousands of loose teeth. Despite these problems we feel we have at least one meaningful result. Fertility appears to have already been increasing in the late Mesolithic and on into the Neolithic. Our results suggest an increase in fertility of around two children per woman within the Mesolithic. We do not know the exact fertility, though our figure suggests a shift from ca. five to ca. seven, but we have some idea of the differential. Our figure suggests a slightly larger increase between Arruda in the Mesolithic and Casa da Moura in the Neolithic, to a fertility perhaps approaching nine. Above all, we have a method by which we can test whether samples provide demographic parameters that are within or outside the bounds of biological reality.

There is independent evidence of the change proposed for the Mesolithic/Neolithic transition in Portugal - a change that begins within the Mesolithic and continues on into the Neolithic, so that a continuous process rather than an "event" must be the interpretation. Dental attrition levels altered (Lubell et al. 1994), suggesting a switch to a progressively softer diet. Independent evidence, based on dental metrics, suggests that the weaning period was shortened (Jackes et al. 1997); along with softer food this would argue for reduced birth intervals. Arruda females were doing something different from Moita females, a shift towards a more sedentary pattern is suggested (Jackes, Lubell 1999), the evidence for this deriving from the internal geometry and density of femoral bone and external features of the femora and tibiae (with a control over the method being provided by Nordin's Index derived from femoral x-rays and control for age by attention to dental wear, and especially by a study of femoral neck $x$ rays). This again suggests circumstances under which more frequent pregnancies would be likely. There is also the suggestive fact that Arruda contains foetal and neonate individuals, based on long bones rather than mandibles. We believe that Arruda was probably a near permanent residential site.

Bocquet-Appel's newly proposed value:

$$
\mathrm{P}=(5-19) /(\text { Total } 5 \text { and over) }
$$

is useful in avoiding some age assessment errors (Bocquet-Appel 2002). Logically, and in actual fact when tested on model data, it is perfectly correlated with mean childhood mortality (MCM) of Figure 22 (x-axis). It has a slightly non-linear relationship with $\mathrm{J}:$ A when tested on model data. Its valid upper value is likely to be 0.350 which is the equivalent of ca $0.380 \mathrm{~J}: \mathrm{A}$, predicting a TF of 12 children. We note that most of Bocquet-Appel's sites fall below $\mathrm{P}=$ 0.350 and we would suggest this as a cut-off value, beyond which bias must be suspected. It is interesting that Bocquet-Appel's high values all derive from samples of small size.

Bocquet-Appel's suggestion of a stationary population for the Mesolithic appears to us justified in general terms based on our work on sites in Scandinavia and in the Iron Gates region of the Danube valley (Meiklejohn et al. 1997; Jackes et al. in press).

We believe we have provided evidence in support of Bocquet-Appel's argument that there was an increase of fertility in the early Neolithic. However, we suggest that the possibility of a demographic trend through time from Moita to Arruda is noteworthy, since independent evidence suggests that the two sites have differences in terms of dental attrition, dental pathology, tooth size, stable isotope central values, cortical thickness and femoral morphology. We absolutely agree that a reduction in the birth interval is the mechanism of population increase, but we see that reduction beginning in the late Mesolithic with an increasingly sedentary life. The differences between the sites are specific and scaled to trends rather than absolutes. We see no evidence of genetic change accounting for the biological differences, no evidence of an incoming population (e.g. Jackes et al. 2001). Absent biological evidence for large-scale population movement, continuity of demographic trends is suggested, and no small group of precursor males would explain the apparent fertility increases in the development and transition from late Mesolithic to early Neolithic.

We have focused here on samples that cover around 2000 years, from 8000 to 6000 calBP, a period of sea level change and some climatic variation. Fertility rates in Europe could have reached our theoretical maximum according to the data used by Bocquet-Appel from Wandersleben (Bach 1980) and Grossbrembach (Ullrich 1972), sites that have adequate samples and fall within the limits of biological reality. But these sites are from the very late LBK or the Bronze Age, and the Early Bronze Age of Central Europe provides sample sizes and age distributions of such diversity (Berner 1992) that the period of 
agricultural intensification appears to require a separate study focusing on the interpretation of the variations.

Leaving aside questions surrounding such later sites, Casa da Moura provides the best data for the European Neolithic in which a considerable increase in fertility can be discerned: yet the site is not ideal because it covers a long period of time (our two dates alone cover 1000 years). We propose that studies of the transition be focused on sites within a restricted geographical area, in which the demographic and biological variations introduced by population movements can be excluded, where there is tight control over dating. The earliest Casa da Moura date calculated at $25 \%$ marine diet certainly overlaps the latest Mesolithic dates for central Portugal, so that we have some assurance that our data are directly relevant to the question of the demography of the transition.

\section{CONCLUSION}

In pointing out the problems associated with the sample of human skeletons from Arruda, we have done no more than is absolutely necessary. Without careful consideration of the nature of the samples, and the methods used to arrive at the estimates of sample size, and without methods of comparison among samples, discussion of Mesolithic/Neolithic transition demography is an unstable foundation. We propose that the methods used across sites of different types must take into account problems arising from burial practices, from excavation and curation and that such methods must be applied with the greatest of care. Far from destroying confidence in the sample, we have developed a method that suggests that our data have some biological validity. It is important that the Portuguese data be approached in such a cautious manner because it is so important in providing us with reasonably large samples across the Mesolithic/Neolithic transition. Although internally consistent, the evidence of a stationary Mesolithic population with low fertility, as previously presented (Meiklejohn et al. 1997; Jackes et al. in press), was based on Scandinavian samples that are not adequate and on Iron Gates material about which some questions remain. More detailed work on the Iron Gates sites presents the best hope of confirming our hypotheses.

The situation in Portugal is simpler than in the Iron Gates region. There is no evidence for large popu- lation replacement and if there were some transcoastal arrivals these seem to have provided no detectable genetic input. It is unlikely that the biology of the indigenous population would have been altered (absent some unknown founder effect) without either population replacement or differential fertility. However, the increase in fertility appears to have been established prior to the Neolithic and increased fertility must be attributed to some alteration of life-way. A reduced birth interval, suggesting earlier weaning, is likely (Jackes et al. 1997). Increasing sedentism and changes in weaning food would be sufficient explanation for this. The evidence thus suggests that the base-camp type settlement at Arruda does indeed provide the appropriate scenario and it appears that Arruda may be more likely than Moita to provide the timing for this along the Muge valley. It is to be noted that a slow and steady increase, rather than a sudden leap in fertility, is proposed. It is also to be noted that total fertility (TF) levels of around eight can be considered as biologically feasible for the early Neolithic in Portugal. At the same time, it is essential to realize that this is a demographic parameter, not an actuality. It is inconceivable that every woman would have had eight children and that every one of those eight children would have grown to reproductive age and had eight children. Nevertheless, we have come closer to an understanding of the timing, mechanism and scale of population increase in central Portugal over the period 8000 to $6000 \mathrm{calBP}$.

\section{NOTE ADDED IN PROOF}

Material from the 1964 excavation has now been moved, and stored with earlier Arruda finds at the Serviços Geológicos in Lisbon. Prior to 2000, the material had undergone at least two periods of flooding (Rolão pers. comm.) and had become mixed. On the basis of a brief examination of the material by Jackes and Lubell in September 2004, we can confirm the number of mandibles seen by Lubell in 2002. However, when the material was moved to the new storage facility, a previously unrecorded skull and mandible were found. Furthermore, another very fragmentary mandible, with a label indicating that it was collected in 1965, has been located by José António Anacleto, Serviços Geológicos, to whom we are indebted for his assistance. 
We wish to acknowledge the work of Portuguese archaeologists during the 19th and early $20^{\text {th }}$ centuries. They were truly ahead of their time. The problems of working with material excavated long ago are legion and it is necessary to document the problems so that we can judge the value of the collections. Material that has been lodged in museums for over 120 years has naturally been subject to the vicissitudes of time. That so much has been preserved and the records are as good as they are demonstrates the sophistication of these early archaeologists. The work reported here has been done with the assistance of many people over a period that now approaches 35 years. Meiklejohn's work in 1969 was supported by a Canada Council Doctoral Fellowship. The work of Jackes and Meiklejohn in the 1980s was supported by two Social Sciences and Humanities Research Council of Canada grants (410-84-0030 and 410-86-2017) in collaboration with David Lubell. Over the years a number of students have assisted us in data collection. Meiklejohn would especially like to thank Catherine T. Schentag, while Jackes would like to acknowledge Pamela Mayne-Correia, Cidália Duarte and Gary Tait for work on Casa da Moura loose teeth. Deborah Ross worked on the methodology of tooth identification. Dr. Gerd Weih's professionalism and general assistance with our Moita and Arruda analyses were invaluable.

A number of colleagues in Portugal contributed significantly to our research. Dr. M. M. Ramalho, now VicePresidente Área Técnico-Científica Instituto Geológico e Mineiro Portugal, authorized access to Muge materials in the 1980s. Dr. J. Brandão, Conservador do Museu Geológico, Lisboa, permitted Lubell access to the 1964 Arruda skeletons and delegated his colleague José António Anacleto who provided invaluable assistance. A. H. Bacelar Gonçalves, Museu de História Natural Faculdade de Ciências da Universidade do Porto, provided essential help in Porto. Dr. J. Rolão, Universidade Autonoma de Lisboa, through his archival work and his current investigations at Muge, greatly faciliated our work. The X-rays were taken at the Janares Clinic, Sintra, by Paulo de Deus Machado.

Jackes thanks Dr. Mihael Budja for his invitation to participate in the Ljubljana conference, and the University of Alberta for a travel grant that covered air fare.

We both thank David Lubell for his support in many areas as part of our long term collaboration and specifically here for photography both of seriated mandibles and of newly discovered Arruda dentitions.

$\therefore$

\section{REFERENCES}

ALVIM P., JACKES M. (in prep.) Reconstructing Moita do Sebastião.

AMMERMANN A. J., BIAGI P. (eds.) 2003. The Widening Harvest The Neolithic Transition in Europe: Looking Back, Looking Forward.

ANGEL J. L. 1969. The bases of paleodemography. American Journal of Physical Anthropology 30: 427-438.

1971. The People of Lerna Analysis of a prehistoric Aegean population. American School of Classical Studies at Athens. Princeton NJ.

ANONYMOUS 1908. Um Grande Sabio Portuguez 0 General Nery Delgado. Illustração Portugueza Edição Semanal do Jornal O Século No $1375^{\text {th }}$ Oct. 1908 Lisbon.

ANTUNES M. T. 1985. Sciurus vulgaris no Cabeço da Arruda, Muge. Presença e extinção em Portugal. Arqueologia 12: 71-84.
ARNAIZ-VILLENA A., LUBELL D. (on behalf of J. Alonso-García, V. Cabrera, J. L. Escacena, M. Jackes, C. Meiklejohn, P. del Moral, P. Rowley-Conwy, M. Ruhlen, A. Sánchez-Mazas). 2000. Prehistoric Iberia: genetics, anthropology and linguistics. Current Anthropology 41: 636-638.

BACH A. 1986. Einige Befunde an den Skeletten aus den Körpergräbern des linearbandkeramischen Gräberfeldes von Wandersleben, Kr. Gotha. Anthropologie (Brno) 24: 111-114.

BERNER M. 1992. Das frühbronzezeitliche Gräberfeld von Franzhausen I, Niederösterreich 2. Demographische Analyse Anthropologischer Anzeiger 50: 13-26.

BOCQUET J-P., MASSET C. 1977. Estimateurs en paléodémographie. L'Homme 7: 65-70.

BOCQUET-APPEL J.-P. 2002. Paleoanthropological traces of a Neolithic demographic transition. Current Anthropology 43: 637-650. 
BRONK RAMSEY C. 2003. OxCal Version 3.9 http:// www.rlaha.ox.ac.uk/orau/index.html

CARDOSO J. L., ROLÃO J. M. 1999/2000. Prospeçcões e escavações nos concheiros mesolíticos de Muge e de Magos (Salvaterra de Magos): contribuição para a história dos trabalhos arqueológicos efectuados. Câmara Municipal de Oeiras. Estudos Arqueológicos de Oeiras 8: 83-240.

CARTAILHAC E. 1886. Les Ages Préhistoriques de L'Espagne et Portugal. Reinwald Librarie. Paris.

CHARBONNEAU H. 1975. Vie et mort des nos ancêtres: Étude démographique. Collection Démographie Canadienne 3, Presses Université de Montréal. Montréal.

COALE A. J., DEMENY P. with VAUGHAN B. 1983. Regional model life tables and stable populations. 2nd ed. Academic Press. New York.

CUNHA E., CARDOSA F., UMBELINO C. 2003. Inferences about Mesolithic lifestyle on the basis of anthropological data. The case of the Portuguese shell middens. In L. Larsson, H. Kindgren, K. Knutsson, D. Loeffler, A. Akerlund (eds.), Mesolithic on the Move: 184-188.

DELGADO J. F. N. 1867. Da existencia do homem no nosso solo em tempos mui remotos provada pelo estudo das caverna. Primeiro opusculo. Noticia ácerca da Grutas da Cesareda. Commissão Geologica de Portugal. Estudos Geologicos. Typographia da Academia Real das Sciencias. Lisbon.

DUARTE C. 1992. Analysis of wear patterns and pathological lesions in human teeth from the Neolithic site of Grutas Artificiais do Tojal de Vila Chà. Unpublished MA thesis, Department of Anthropology, University of Alberta.

EATON J. W., MAYER A. J. 1953. The social biology of very high fertility among the Hutterites: the demography of a unique population. Human Biology 25: 206-264.

FEREMBACH D. 1974. Le gisement mésolithique de Moita do Sebastião, Muge, Portugal. II. Anthropologie. Direcção-Geral do Assuntos Culturais. Lisbon.

HERVÉ G. 1899. Populations mésolithiques et néolithiques de L'Espagne et du Portugal. Revue de l'Ecole d'Anthropologie de Paris 9: 265-280.
HOWELL N. 1979. Demography of the Dobe !Kung (1st ed.). Academic Press. New York.

JACKES M. 1985. Pubic symphysis age distributions. American Journal of Physical Anthropology 68: 281-299.

1992. Paleodemography: problems and techniques of analysis. In S. R. Saunders and M. A. Katzenberg (eds.), The Skeletal Biology of Past Peoples: Advances in Research Methods: 189-224.

1994. Birth rates and bones. In A. Herring and L. Chan (eds.), Strength in Diversity: a Reader in Physical Anthropology: 155-185.

1998. Osteological data and prehistoric Iberia: limitations and possibilities. Invited paper for symposium on Prehistoric Iberia: Anthropology, Linguistics and Genetics. Madrid, Spain, November 1998.

2000a. Building the bases for paleodemographic analysis: adult age determination. In M. A. Katzenberg and S. R. Saunders (eds.), Biological Anthropology of the Human Skeleton: 417-466.

2000b. Ethnohistory and osteology in southern Ontario. In M. Boyd, J. C. Erwin, M. Hendrickson (eds.), The Entangled Past: Integrating History and Archaeology. Papers of the 30th Annual Chacmool Conference Calgary: 164-174.

JACKES M., LUBELL D. 1995. Dental pathology and diet: second thoughts. In M. Otte (ed.), Nature-Culture: relation de biologie à l'histoire en archéologie préhistorique: 455-478.

1999. Human biological variability in the Portuguese Mesolithic. Arqueologia 24: 25-42.

JACKES M., LUBELL D., MEIKLEJOHN C. 1997. Healthy but mortal: human biology and the first farmers of Western Europe. Antiquity 71: 639-658. Additional material on-line. http://intarch.ac.uk/antiquity/ jackes/jlind.html

JACKES M., MEIKLEJOHN C. (in prep.) Demography and Moita do Sebastião.

JACKES M., ROKSANDIĆ M., MEIKLEJOHN C., and LUBELL D. (in press.) The Demography of the Iron Gates Samples and its Relationship to other European Mesolithic Samples. Conference on Iron Gates Gorge. Edinburgh, April 2000. Archaeopress. Oxford. 
JACKES M., SILVA A. M., IRISH J. 2001. Dental morphology: a valuable contribution to our understanding of prehistory. Journal of Iberian Archaeology 3: 97-119.

KALB P. 1989. O megalitismo e a neolitização no oeste da peninsula iberica. Arqueologia 20: 33-48.

LEFÈVRE J. 1972. La Denture des Hommes du Mésolithique Portugais. Thèse pour le doctorat en chirurgie dentaire (troisième cycle). Université de $\mathrm{Pa}$ ris VII.

LENTACKER A. 1986. Preliminary results of the fauna of Cabeço de Amoreira and Cabecço de Arruda (Muge, Portugal). Trabalhos de Antropologia e Etnologia (Porto) 26: 9-26.

1991. Archeozoölogisch Onderzoek Van Laat Prehistorische Vindplaatsen Uit Portugal. Unpublished Ph.D. thesis, Laboratorium voor Paleontologie, Faculteit Wetenschappen, Rijksuniversiteit, Gent.

LUBELL D., JACKES M. 1985. Mesolithic-Neolithic continuity: evidence from chronology and human biology. In M. Ramos (ed.), Actas, I Renunião do Quaternário Iberico: 113-133.

LUBELL D., JACKES M., MEIKLEJOHN C. 1989. Archaeology and human biology of the Mesolithic-Neolithic transition in southern Portugal. In C. Bonsall (ed.), The Mesolithic in Europe: Papers Presented at the Third International Symposium, Edinburgh 1985: 632-640.

LUBELL D., JACKES M., SCHWARCZ H., KNYF M., MEIKLEJOHN C. 1994. The Mesolithic-Neolithic transition in Portugal: isotopic and dental evidence of diet. Journal of Archaeological Science 21: 201216.

MCDANIEL A. 1992. Extreme mortality in nineteenth century Africa: the case of Liberian immigrants. $D e$ mography 29: 581-594.

MEIKLEJOHN C. 1974. The biosocial basis of Upper Palaeolithic and Mesolithic man in Western Europe. Unpublished PhD thesis, University of Toronto.

MEIKLEJOHN C., ZVELEBIL M. 1991. Health status of European populations at the agricultural transition and the implications for the adoption of farming. In H. Bush \& M. Zvelebil (eds.), Health in Past Popula- tions. British Archaeological Reports International Series 567: 129-145.

MEIKLEJOHN C., BALDWIN J. H., SCHENTAG C. T. 1988. Caries as a probable dietary marker in the Western European Mesolithic. In B. V. Kennedy and G. M. LeMoine (eds.), Diet and Subsistence: Current Archaeological Perspectives: 273-279.

MEIKLEJOHN C., WYMAN J. M., JACOBS K., JACKES M. 1997. Issues in the archaeological demography of the agricultural transition in western and northern Europe: a view from the Mesolithic. In R. R. Paine (ed.), Integrating Archaeological Demography: multidisciplinary approaches to prehistoric populations. Center for Archaeological Investigations, Occasional Paper No. 24. Southern Illinois University. Carbondale: 311-326.

MEIKLEJOHN C., BRINCH PETERSEN E., ALEXANDERSEN V. 1998. The Later Mesolithic Population of Sjalland, Denmark, and the Neolithic Transition. In M. Zvelebil, R. Dennell and L. Domańska (eds.), Harvesting the Sea, Farming the Forest: The Emergence of Neolithic Societies in the Baltic Region and Adjacent areas: 203-212.

MONGE SOARES A. M. 1993. The ${ }^{14} \mathrm{C}$ content of marine shells: evidence for variability in coastal upwelling off Portugal during the Holocene. Isotope techniques in the Study of past and Current Environmental Changes in the Hydrosphere and Atmosphere (Proceedings) Vienna: 471-485.

NEWELL R. R., CONSTANDSE-WESTERMANN T., MEIKLEJOHN C. 1979. The skeletal remains of Mesolithic man in Western Europe: an evaluative catalogue. Journal of Human Evolution 8: 1-228.

PAULA E OLIVIERA F. 1889. Nouvelles fouilles faites dans les kioekkenmoeddings de la vallée du Tage (posthumous publication). Communicações da Commissão dos Trabalhos Geologicos II (i): 57-81.

PEREIRA DA COSTA F. A. 1865. Da existencia do homem em epochas remotas no valle do Tejo Primeiro opusculo Noticia sobre os esqueletos humanos descobertos no Cabeço da Arruda. Imprensa Nacional. Lisbon.

PRICE T. D. (ed.) 2000. Europe's First Farmers. Cambridge University Press. Cambridge.

RIBEIR0 C. 1880. Les kioekkenmoeddings de la vallée du Tage. Congrès International d'Anthropologie 
et d'Archéologie Prehistoriques Neuvième Session: 279-291.

ROCHE J. 1957. Premiere datation du Mésolithique portugais par la méthode du Carbone 14. Boletim da Academia das Ciências de Lisboa. n.s. 24: 292-298.

1965a. Observations sur la stratigraphie et la chronologie des amas coquilliers mésolithiques de Muge (Portugal). Bulletin de la Société Préhistorique française 62: 130-138.

1965b. Données récentes sur la stratigraphie et la chronologie des amas coquilliers d'âge mésolithique de Muge (Portugal). Quaternaria. Roma 7: 155-163.

1972a. Le gisement mésolithique de Moita do Sebastião Muge Portugal. I Archéologie. Instituto de Alta Cultura. Lisbon.

1972b. Les amas coquilliers (concheiros) mésolithique de Muge (Portugal) Die Anfänge des Neolithikums vom Orient bis Nordeuropa Westliches Mittelmeergebiet und Britische Inseln. Fundamenta 8: 72-107.

ROCHE J., FERREIRA 0. da Veiga 1972-1973. Seconde datation par le C14 de l'amas coquillier mésolithique de Moita do Sebastião. Communicações dos Serviços Geológicos de Portugal, LVI: 471-476.

ROKSANDIĆ M. (in press.) Analysis of Burials from the New Excavations of the Sites Cabeço da Amoreira and Arruda (Muge, Portugal) Muge. Estudos Arqueológicos 2.

van der SCHRIEK T. (in prep.) Holocene environmental change and the alluvial geoarchaeology of Mesolithic settlement-subsistence in the Muge and Magos valleys, Lower Tagus Basin, Portugal. Submitted January $2004 \mathrm{PhD}$, University of Newcastle upon Tyne. van der SCHRIEK T., PASSMORE D. G., FRANCO MUGICA F., STEVENSON A. C., BOOMER I., ROLÃO J. 2003. The geoarchaeology of prehistoric subsistence and settlement in the Muge valley, Lower Tagus Basin, Portugal. In Howard A. J., Macklin M. G., Passmore D. G. (eds.), Alluvial Archaeology in Europe - Proceedings of the Alluvial Archaeology of NorthWest Europe and Mediterranean Conference, Leeds, 18-19 December 2000: 217-227.

SOARES A. M., CABRAL J. M. P. 1984. Datas convencionais de radiocarbono para estações arqueológicas Portuguesas e a sua calibração: revisão crítica, $O A r$ queólogo Português 2: 167-214.

STRAUS L. G., ALTUNA J., JACKES M., KUNST M. 1988. New excavations in Casa da Moura (Serra d'el Rei, Peniche) and at the Abrigos de Bocas (Rio Maior), Portugal. Arqueologia (Porto) 18: 65-95.

SUEIRO M. B. Barbosa, FRAZÃO J. Vasconcelos 1959. Lesões dentárias no homem do mesolítico português Nota de paleopatologia. Arquivo de Anatomia e Antropologia (Lisbon) 30: 197-209.

TAUBER H. 1981. 13C evidence for dietary patterns of prehistoric man in Denmark. Nature 292: 332333.

ULLRICH H. 1972. Das Aunjetitzer Gräberfeld von Grossbrembach. Part 1. Hermann Boehlaus. Weimar.

UNITED NATIONS 1982. Model Life Tables for Developing Countries. Department of International Economic and Social Affairs Population Studies No. 77. United Nations. New York.

VALLOIS H. V. 1930. Recherches sur les ossements Mésolithiques de Mugem. L'Anthropologie 40: 337389. 